\title{
In glacial environments beyond glacial terrains: Human eco-dynamics in late Pleistocene Mediterranean Iberia
}

\author{
C. Michael Barton ${ }^{\mathrm{a}, *}$, Valentin Villaverde ${ }^{\mathrm{b}}$, João Zilhão ${ }^{\mathrm{c}}$, J. Emili Aura ${ }^{\mathrm{b}}$, Oreto Garcia ${ }^{\mathrm{b}}$, \\ Ernestina Badal ${ }^{\text {b }}$ \\ a School of Human Evolution and Social Change, Arizona State University, PO Box 872402, Tempe, AZ 85287-2402, United States \\ ${ }^{\mathrm{b}}$ Departament de Prehistòria i Arqeologia, Universitat de València, Spain \\ ${ }^{\mathrm{c}}$ Departament de Prehistòria, Història Antiga i Arqueologia, Universitat de Barcelona/Institució Catalana de Recerca i Estudis Avançats, Spain
}

\section{A R T I C L E I N F O}

Article history:

Available online $\mathrm{xxx}$

\begin{abstract}
A B S T R A C T
The Iberian Peninsula south of the Ebro River enjoyed one of the mildest climates of Pleistocene Europe, but still experienced significant and rapid environmental shifts caused by global climate regimes. We examine the interplay between technological, social, and land-use dynamics as culturally mediated responses to climate change outside the periglacial zone. We combine information from excavated sites across eastern and southeastern Spain with systematic survey data from an intensive study area within this larger region to examine Upper Paleolithic behavioral adaptations to the environmental shifts of the late Pleistocene (late MIS-3 through MIS-2). We define indexes that serve as proxies for land-use strategies, technological specialization, and hunting practices. Variation in these indices across space and through time provides the basis for a model of Upper Paleolithic eco-dynamics. A consistent pattern of land-use, involving inland (and possibly coastal) base-camps and near-coastal hunting zones spanned the Mediterranean facade and was sufficiently flexible and resilient to environmental change to persist throughout the late Pleistocene.
\end{abstract}

(c) 2013 Elsevier Ltd and INQUA. All rights reserved.

\section{Introduction}

Many think of the late Pleistocene as the "Ice Age", a time when continental glaciers covered much of the earth and where the land not under ice was inhabited by giant cold-adapted animals-wooly mammoth, wooly rhinoceros, and cave bears-pursued by hardy human hunters. While this image may be somewhat accurate for part of the world, most of the earth remained unglaciated throughout the Pleistocene. This world beyond glacial terrains experienced important climate-driven environmental change, however. Climate directly affected plant and animal communities on which humans depended and indirectly affected environments through sea-level changes; human ecological behaviors reconfigured in order to adapt to these shifts across time and space.

The Iberian Peninsula represents the largest region of Europe beyond glacial terrains. With a rich heritage of archaeological research, highly diverse biophysical landscapes, and a record of human occupation extending over a million years (Carbonell et al., 2008), the peninsula offers an excellent opportunity to study the eco-dynamics of long-established human populations in relation to

\footnotetext{
* Corresponding author.

E-mail address: michael.barton@asu.edu (C.M. Barton).
}

the environmental changes of the last glacial maximum (LGM) and its aftermath-beyond the direct impacts of continental glaciation. We focus here on spatial/temporal dynamics of human huntergatherer ecology in the Mediterranean facade of the Iberian Peninsula, extending from the foothills of the Pyrenees to the Straits of Gibraltar (Fig. 1), over an approximately $20 \mathrm{ky}$ span of the late Pleistocene (i.e., from ca. 30-10 ka) that encompasses the Upper Paleolithic in this region. This study builds on prior research on late Pleistocene ecology in this region that has examined settlement, animals consumed (especially the importance of small prey and marine resources relative to terrestrial ungulates), and the complementary use of coastal and interior zones at regional scales (Davidson, 1976, 1989; Martínez Valle, 2001; Aura Tortosa et al., 2002b, 2009; Pérez Ripoll, 2004).

As noted above, even though Mediterranean Spain was well south of the temperate glacial environments associated with continental ice sheets in Europe, climate, vegetation, and fauna of the late Pleistocene were different from those of Holocene environments. Many of the same plants found today in the Iberian Peninsula made up late Pleistocene communities, but they were distributed differently from today geographically and attitudinally; plant associations that formed communities also differed. On the basis of pollen and charcoal evidence, much of Mediterranean Spain seems to have been dominated by cool coniferous forest prior 


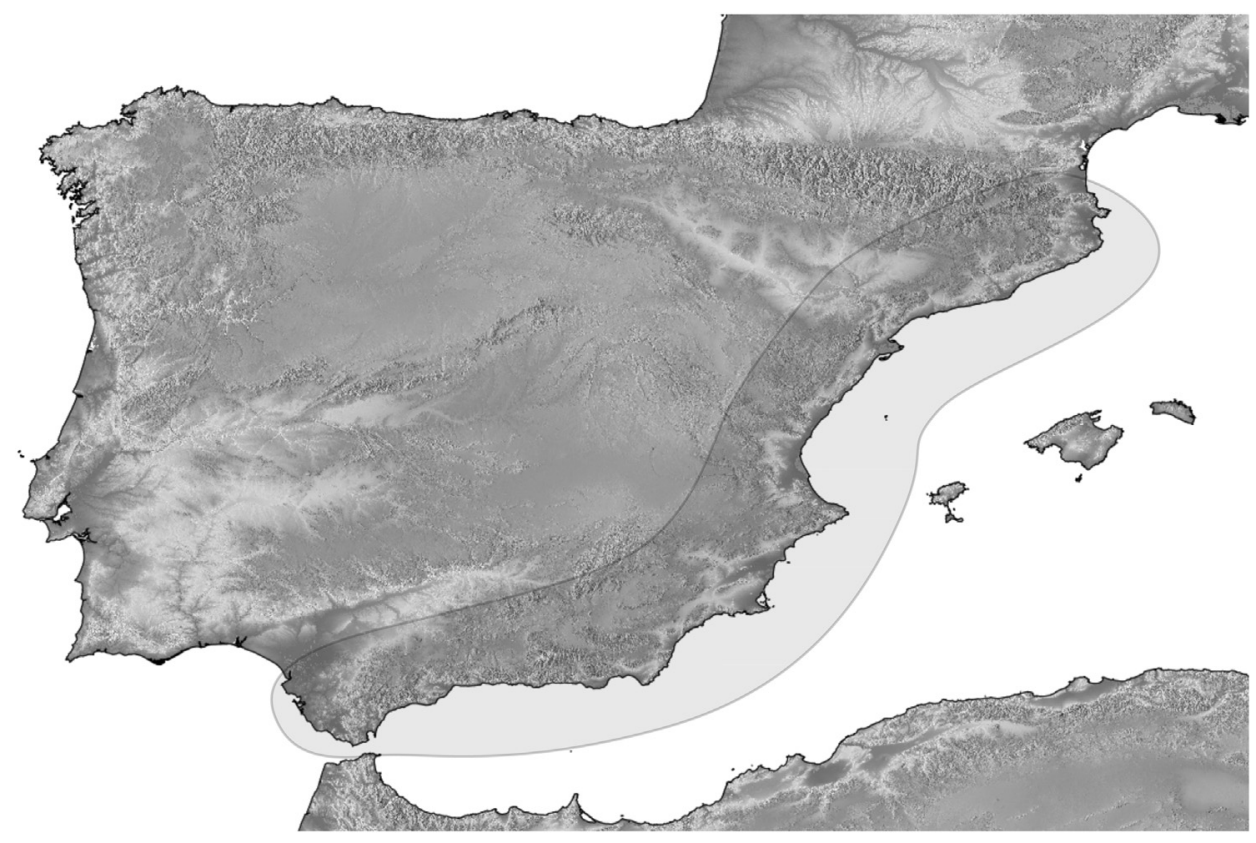

Fig. 1. The Iberian Peninsula and the Mediterranean zone discussed in this paper.

to the LGM (Fig. 2). North of $40^{\circ} \mathrm{N}$, forests were dominated by Pinus sylvestris; to the south, warmer and drier conditions favored a mix of P. sylvestris and Pinus nigra; along the coast of Andalucia, Pinus pinea (whose nuts are found in Paleolithic sites) joined the mixed pine forest (Badal Garcia, 1998; Jorda Pardo and Aura Tortosa, 2008; Carrión et al., 2010; Jorda Pardo et al., 2011; Carrión, 2012; Villaverde Bonilla et al., 2012).

These pre-LGM forests were replaced by open vegetation in many areas during the LGM - cold, dry step and shrub communities with scattered stands of pine and juniper ( $P$. nigra, $P$. sylvestris, and Juniperus sp.). Following the LGM, these open landscapes came to be increasingly wooded, initially by cool temperate pine forest $(P$ nigra and $P$. sylvestris), and subsequently by increasing frequencies

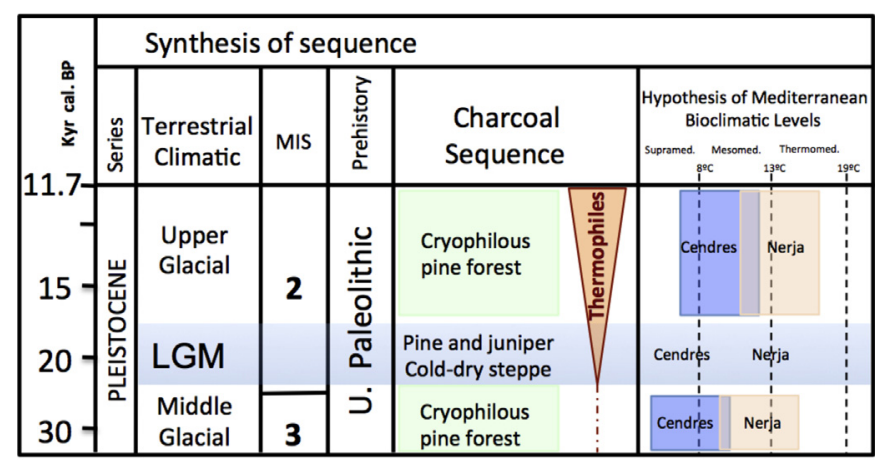
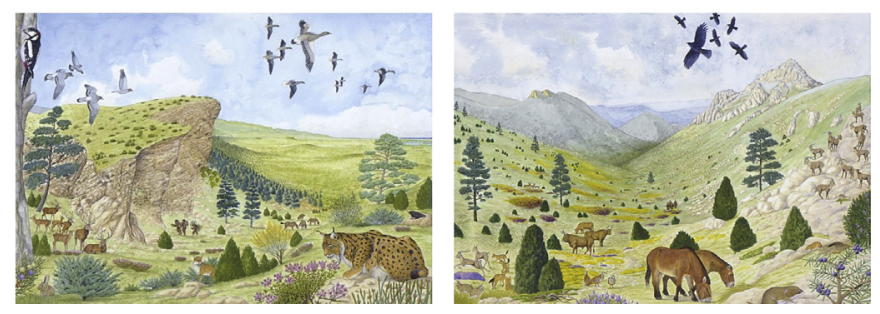

Fig. 2. Synthesis of late Pleistocene environmental changes in Mediterranean Spain in illustrations of landscapes in the region for the LGM at Parpalló Cave (right) and end Pleistocene at Cendres Cave (left). of taxa that characterize the modern Mediterranean woodland (e.g., evergreen and deciduous Quercus sp., Acer, Fraxinus). Warm Mediterranean taxa such as Olea europaea, Pistacia lentiscus, and Rosmarinus officinalis, especially, become more common in sites from the southernmost parts of the zone (Carrión Marco, 2005; Aura Tortosa et al., 2010; Carrión Marco et al., 2010; Villaverde Bonilla et al., 2010). The Mediterranean woodland of today is a characteristic of the Holocene, when it spread from Pleistocene refugia in the south of the peninsula (Badal Garcia, 1998; Jorda Pardo and Aura Tortosa, 2008; Carrión Marco et al., 2010; Jorda Pardo et al., 2011; Carrión, 2012; Villaverde Bonilla et al., 2012).

Temperatures and vegetation communities structured the animal communities that inhabited the landscape. During the LGM, open-country taxa such as Equus and Bos were common, but were replaced by more woodland associated taxa such as deer in the late glacial (Davidson, 1989; Pérez Ripoll and Martínez Valle, 2001; Aura Tortosa et al., 2002b).

Forager socio-ecology is responsive to environmental conditions, especially with respect to critical animal and plant resources. In part, this means that foragers must adapt their subsistence to naturally available resources and shift them along with changing environmental conditions. But more importantly, known foragers reconfigure more inclusive land-use strategies to adapt to spatial/ temporal distributions of resources (Kelly, 1992, 1995; RielSalvatore and Barton, 2004; Grove, 2009). For example, open country grazers living in large herds, like horses have a more clumped distribution in space and time than forest browsers like roe deer (Pérez Ripoll and Martínez Valle, 2001); small game must be collected with greater temporal frequency than large game and may require additional fat supplements year round (e.g., in the case of hares) rather than only in the lean season of late winter (Speth and Spielmann, 1983). However, we cannot observe prehistoric socio-ecological systems in action, and must rely on proxy data as the empirical source of information about past systems.

For late Pleistocene hunter-gatherers, the primary behavioral proxies are in the form of stone artifacts that they used and discarded, and the bones of animals that they hunted and ate. This is an admittedly narrow perspective on the total range of prehistoric activities. Even though we know that mobile foragers made use of 
their entire home range in diverse ways, we are usually limited to the very tiny windows of excavated archaeological sites to provide archaeological materials for study, most of which are in caves and rock shelters that were atypical of the majority of locales occupied by these people.

Additionally, recent foragers-and presumably those of the late Pleistocene too-employ highly flexible behavioral strategies to respond to the variable distribution of different resources across space, and their changes at the daily, seasonal, annual, and decadal scales which are most relevant for human lifetimes. We should expect archaeological residues of Paleolithic hunter-gatherers to likewise vary with geographically local and short term environmental conditions. The relatively few sites and palimpsest assemblages that comprise the studied portion of the archaeological record in this region (see below), are so dispersed in space and time that it is unlikely that any one is representative of the regional-scale foraging systems and adaptations to climate-driven changes in late glacial environments.

Nevertheless, as we show below, theoretically grounded, quantitative analyses of stones and bones from these localities can provide valuable information about the eco-dynamics of the late Pleistocene inhabitants of Mediterranean Spain. Moreover, our emphasis here is on human ecology at the scale of the geographically broad region of Mediterranean Iberia rather than the particular activities of hunter-gatherers at any particular locale and moment in the past. Employing a regional-scale analytical approach, that integrates data from multiple sources, helps to identify important spatial and temporal adaptive strategies that are not apparent at the level of individual sites. surface collections. These assemblages encompass named archaeological industries of Aurignacian through Magdalenian, spanning approximately $20 \mathrm{ka}$. While there are radiocarbon dates for some of the excavated assemblages, many lack direct numerical dating, as do all of the surface assemblages. However, we can reliably group the excavated collections chronologically into Pre-LGM (Gravettian and Aurignacian), LGM (Solutrean), PostLGM (Magdalenian) intervals for consistent comparison across all sites (we also include a set of Holocene assemblages as a comparative baseline for temporal change across Pleistocene assemblages). These temporally coarse divisions also offer the potential for broad comparisons with other regions of the peninsula such as the Pyrenees, Cantabria, and Atlantic facade (Aura and Pérez-Ripoll, 1995; Aura Tortosa et al., 1998, 2010, 2012; Villaverde et al., 1998; Villaverde Bonilla, 2001; Villaverde Bonilla et al., 2010, 2012; Zilhão et al., 2010).

The surface collections can only be divided chronologically into early (pre-Magdalenian) and late (Magdalenian) Upper Paleolithic (we did not analyze surface Holocene lithics here) on the basis of "Temporal Index" for surface collections, described in detail in prior publications (Barton et al., 1999, 2002, 2004; Bernabeu Aubán et al., 1999; Bernabeu et al., 2000). Because this division differs from the slightly higher chronological resolution of the excavated assemblages, we consider the surface collections separately from excavated materials, although we perform the same analyses on all materials. Early and Late Upper Paleolithic assemblages were combined for the analyses of the surface collection reported below. The sites and surveys are shown in Figs. 3 and 4, and listed in Table 1.

Table 1

Sites used for analysis

\begin{tabular}{|c|c|c|c|c|c|}
\hline Site & Map number & Region & Latitude & Longitude & References \\
\hline Gorham's Cave & 1 & Gibraltar & 36.120397 & -5.342075 & Waechter, 1951, 1964; Barton, 1988, 1998 \\
\hline Cueva de Nerja & 2 & Nerja, Málaga & 36.762278 & -3.845097 & Aura Tortosa et al., 2002a, 2010 \\
\hline El Pirulejo & 3 & Córdoba & 37.434222 & -4.183750 & Cortés Sánchez, 2010 \\
\hline Ambrosio & 4 & Almeria & 37.822211 & -2.099089 & Ripoll López, 1988 \\
\hline Falguera & 5 & Alcoi, Alacant & 38.672709 & -0.566478 & García Puchol and Aura Tortosa, 2006 \\
\hline Cova de les Cendres & 6 & Teulada, Alacant & 38.685899 & 0.152185 & Villaverde Bonilla et al., 1999, 2010 \\
\hline Santa Maira & 7 & Castell de Castells & 38.730285 & -0.215087 & Aura Tortosa, 2001; Aura Tortosa et al., 2006 \\
\hline Benamer & 8 & Muro, Alacant & 38.785172 & -0.411434 & Torregrosa et al., 2011 \\
\hline Tossal de la Roca & 9 & Vall d'Alcalà, Alacant & 38.790155 & -0.281049 & Cacho Quesada et al., 1995 \\
\hline Beneito & 10 & Muro, Alacant & 38.798147 & -0.465982 & $\begin{array}{l}\text { Iturbe Polo and Perez, 1982; Iturbe et al., 1993; } \\
\text { Villaverde et al., } 1998\end{array}$ \\
\hline Parpalló & 11 & Gandia & 39.004103 & -0.27131 & $\begin{array}{l}\text { Fullola Pericot, 1979; Davidson, 1989; Aura and } \\
\text { Pérez-Ripoll, 1995; Villaverde Bonilla et al., } 2010\end{array}$ \\
\hline Cova dels Blaus & 12 & Vall d’Uixó, Castelló & 39.841456 & -0.201637 & Casabó, 2004 \\
\hline Matutano & 13 & Vilafamés, Castelló & 40.114468 & -0.050041 & Olària, 1999; Casabó, 2004 \\
\hline La Roureda & 14 & Vilafranca, Els Ports & 40.458027 & -0.309472 & Román Monroig, 2010 \\
\hline Cingle de L'Aigua & 15 & Xert, Castelló & 40.541400 & 0.164488 & Román Monroig, 2010 \\
\hline Cova del Parco & 16 & Alós Balaguer, Lleida & 41.872014 & 1.231821 & Mangado Llach et al., 2007 \\
\hline
\end{tabular}

\section{Proxy data for late glacial eco-dynamics}

The proxy data for late Pleistocene eco-dynamics used here come from a series of excavated, stratified archaeological sites spanning all of Mediterranean Spain, and from a series of patchbased surveys in the central part of this larger region. The excavated data include 37 assemblages from 16 stratified sites. The excavated assemblages represent 279,708 lithic artifacts, 4048 bone artifacts, and 90,402 animal bones or identifiable bone fragments. Additionally, we include 7760 lithic artifacts from 417 surface collection units in five valleys in the Valencian Region. No bones or bone artifacts were recovered from these
The presence of stone artifacts and animal bones indicates that humans were present and butchering animals, but these raw data are not in and of themselves very informative about human ecology and its spatial/temporal dynamics. Hence, we calculate a set of quantitative indices from the raw lithic and faunal data, based in Human Behavioral Ecology and middle-range theory of lithic technology, designed to provide information about prehistoric ecological behaviors at regional scales. These include indices of land-use strategies, specialization in hunting weapons, and general hunting strategies. We also track some basic but ecologically important information about the locations of sites and survey collections. Climate and, consequently, plant and animal communities 


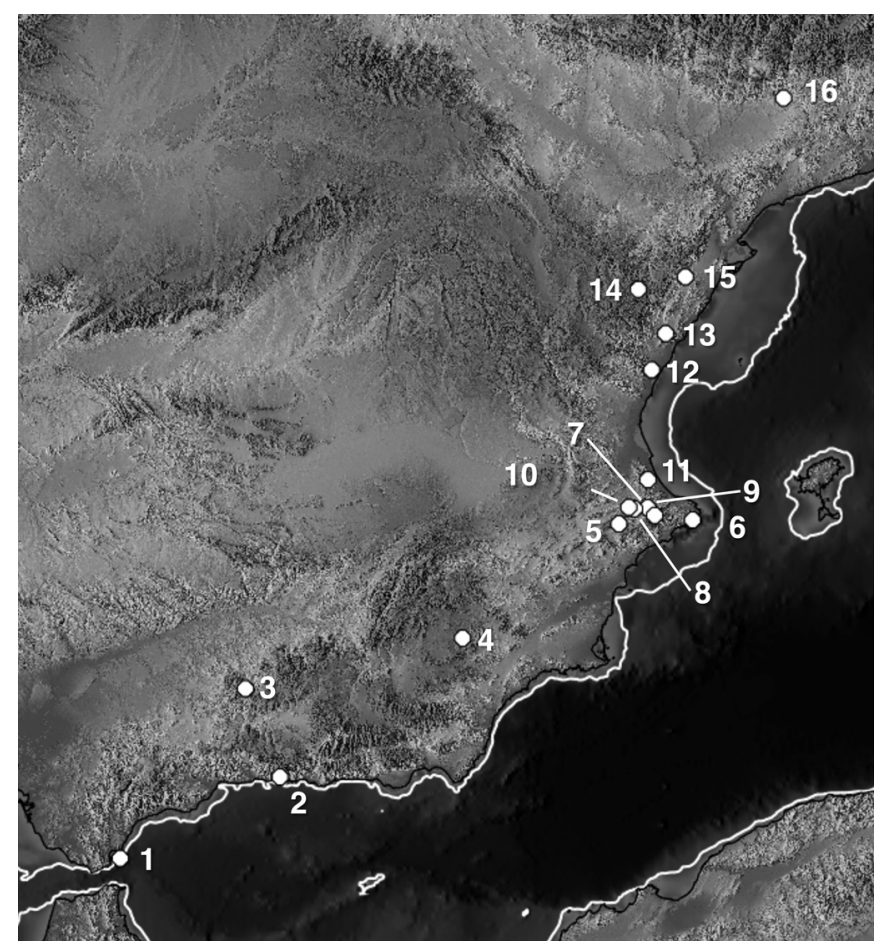

Fig. 3. Locations of sites discussed in text (see Table 1) and LGM coastline (white line) superimposed on modern configuration of the Iberian Peninsula (modern coastline in black). Sites are: Gorham's Cave (1), Cueva de Nerja (2), El Pirulejo (3), Ambrosio (4), Falguera (5), Cova de les Cendres (6), Santa Maira (7), Benamer (8), Tossal Roca (9), Beneito (10), Parpalló (11), Cova dels Blaus (12), Matutano (13), La Roureda (14), Cingle de L'Aigua (15), Cova del Parco (16).

vary with altitude in the Iberian Peninsula. Related to this variation are the distances of sites from the Mediterranean coast, as elevations generally rise as one moves inland from the Pleistocene coastal plain. There are also indications that foragers may have moved seasonally from coastal to inland localities to access different resources (Villaverde Bonilla and Martínez Valle, 1995; Villaverde et al., 1998; Pérez Ripoll and Martínez Valle, 2001; Aura Tortosa et al., 2002b, 2009; Villaverde Bonilla et al., 2012). Finally, environments vary latitudinally along the Mediterranean facade and, in the late Pleistocene, also represented the distance from glacial terrains north of the Pyrenees. We discuss these measures in more detail below. Artifact counts and indices for all assemblages are shown in Supplementary Information Tables 1 and 2.

\section{Land-use strategies}

Studies of recent hunter-gatherers indicate important relationships between the spatial/temporal distribution of resources, mobility of human groups, and spatial/temporal patterning in the occupation of campsites. In numerous studies of European Paleolithic assemblages, retouch frequency has been shown to be a robust proxy for land-use strategy (Barton, 1998; Kuhn, 2004; RielSalvatore and Barton, 2004, 2007; Sandgathe, 2006; Clark, 2008; Riel-Salvatore et al., 2008; Barton et al., 2011). It most directly responds to residence time and individual versus place provisioning (sensu Kuhn, 1992), which in turn, have been associated with variation between residential and logistical mobility and foraging patterns (Binford, 1980; Kelly, 1992, 1995; Grove, 2009).

Residential mobility refers to land-use patterns in which huntergatherers move their residential camps from resource patch to resource patch within a home range or territory as resources become more and less abundant throughout the year. Because they move camps often and stay at camps for short times, residentiallymobile hunter-gatherers emphasize provisioning individuals with the items they need on a regular basis, and portability is an important concern for material culture. This land-use strategy favors extending the use-life of lithic artifacts through reuse and resharpening. Hence, their discarded lithic assemblages have relatively few artifacts and are dominated by heavily curated and reused (i.e., retouched) pieces. We refer to the camps of residentially mobile hunter-gatherers as residential camps here.

Logistical mobility refers to a different land-use strategy in which hunter-gatherers remain in a camp, often called a base camp, for longer durations than do residentially mobile hunter-gatherers. They send out foraging parties to specifically targeted resource patches and then bring the resources back to the base camp, where they are consumed by all members of the group. With logistical mobility, however, groups can provision longer-occupied base camps with stockpiled lithic raw material. This results in greater numbers of artifacts being produced and discarded, without the need for curation and reuse. Hence, these assemblages have lower frequencies of retouched lithic artifacts. For foraging parties who travel from base camps to targeted resource patches (i.e., to bring resources back to base camps), however, portability in material culture is as important as it is for residentially mobile groups and

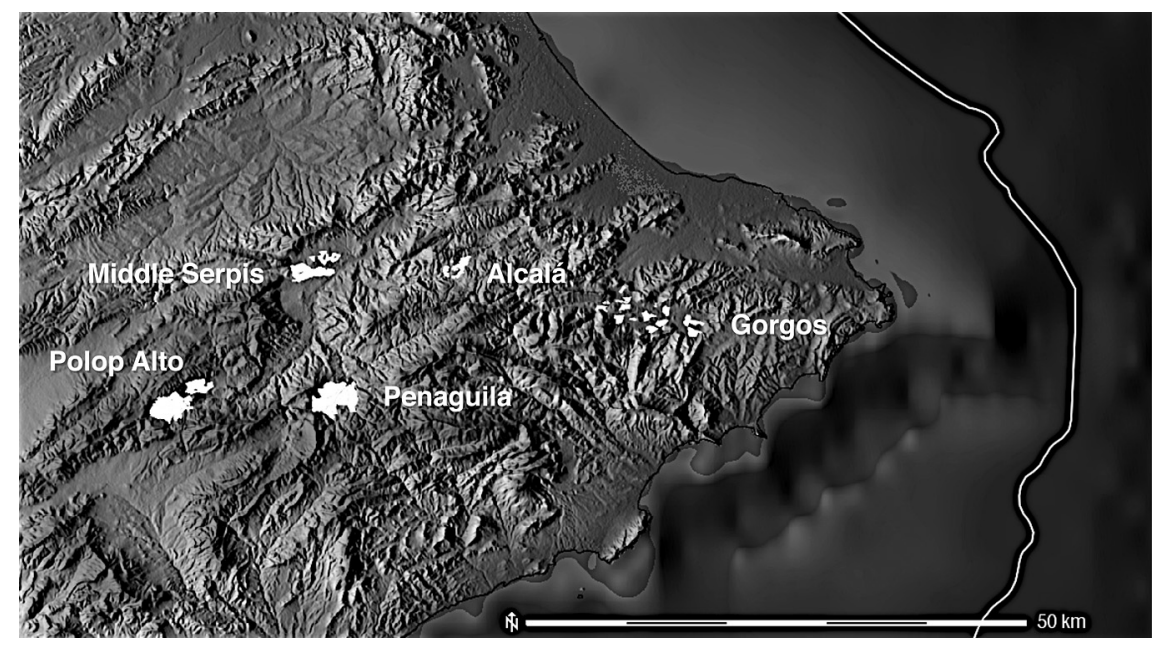

Fig. 4. Locations of survey units (white) in central Valencian Region (Barton et al., 2004). LGM coastline shown by white line and modern coast indicated by black line. 
we expect the assemblages discarded in camps associated with these targeted resource forays to be characterized by few artifacts and more curation. We refer to such camps as resource acquisition camps or sometimes simply hunting camps in this paper.

We use retouch frequency, indicating the importance of curation of lithic utility through reuse and resharpening, as a proxy index for these land-use strategies (Barton, 1998; Riel-Salvatore and Barton, 2004; Riel-Salvatore et al., 2008; Barton et al., 2011). A key test of the relationship between lithic artifact curation and land-use strategies is a strong negative correlation between retouch frequencies and total artifact density per unit volume of sediment for assemblages accumulating in stratified deposits (Riel-Salvatore and Barton, 2004, 2007; Riel-Salvatore et al., 2008). Miller and Barton (2008) suggest the possibility of using an analogous comparison between retouch frequency and artifact density per unit area for surface collections. Fig. 5 shows retouch frequency versus surface artifact density for all survey units with likely Upper Paleolithic materials (see Barton et al., 1999, 2002). There is a clear and significant negative correlation between these two measures, indicating that retouch frequency can serve as a proxy for land-use in the survey collections as well as in the assemblages from excavated sites.

From all contexts, but especially from stratified cave and shelter sites, the collections of lithic artifacts recovered by archaeologists are likely to be time-averaged palimpsests of multiple occupations rather than discard assemblages from a single use of a site. Hence, variation in retouch frequency is a proxy for the relative importance of residential versus logistical land-use strategies over some time interval, even though foragers may utilize either mobility pattern at different times during the interval. A related consideration is that very few artifacts will likely be discarded at a single occupation residential camp or a targeted resource acquisition camp associated with a logistical strategy. Hence, it is unlikely that such places will be identifiable archaeologically unless they have been repeatedly occupied (e.g., a stratified cave or shelter site), and especially occupied at least sometimes as a base camp where technological behaviors will result in the discard of sufficient quantities of artifacts to be archaeologically visible-and attractive for investing the time and resources for excavation. This means that the available sample of excavated Upper Paleolithic sites is biased towards base camps, a point to which we return later. A possible exception to this is the material from patch-based survey. Even very low densities of lithics were recorded in this fieldwork, meaning that these collections may also include residues of residential camps and targeted resource acquisition forays.

\section{Specialized hunting technology}

Portability in material culture is important to residential foragers. It is equally important-and possibly more so-to logistically organized foragers when they engage in long-distance resource forays. Specialized hunting weapons of the Upper Paleolithic-hafted points with microlithic armatures, bone foreshafts, detachable bone harpoons, etc.-are both highly portable and maintainable in the field (e.g., replacing broken microliths). They may also produce more reliable results (i.e., in terms of killing an animal) than a simple sharpened wood spear because the stone armatures help embed the tip in an animal and increase blood loss (see Torrence, 1989). However, these kinds of tools require considerable more labor to produce initially than simpler wooden spears or expedient flakes. This is suited to the kind of time distribution of logistically organized foragers who can spend more time at base camps 'gearing-up' for periodic resource forays. They are also well suited to hunting (including hunting sea mammals) that involves long-distance forays, where prey may be fieldprocessed to lighten the load in bringing resources back to a central base camp (Metcalf and Barlow, 1992).

We combine the relative frequencies of microlithic backed pieces and bone artifacts into a composite index of specialized weapons technology, the technological specialization index, which indicates the importance of such logistical resource forays relative to local and more expedient resource acquisition. Note that among many foragers, both kinds of resource extraction are practiced; this index is a proxy for variation in the importance of logistical forays.

Land-use (retouch frequency \& lithic density): Survey Patches

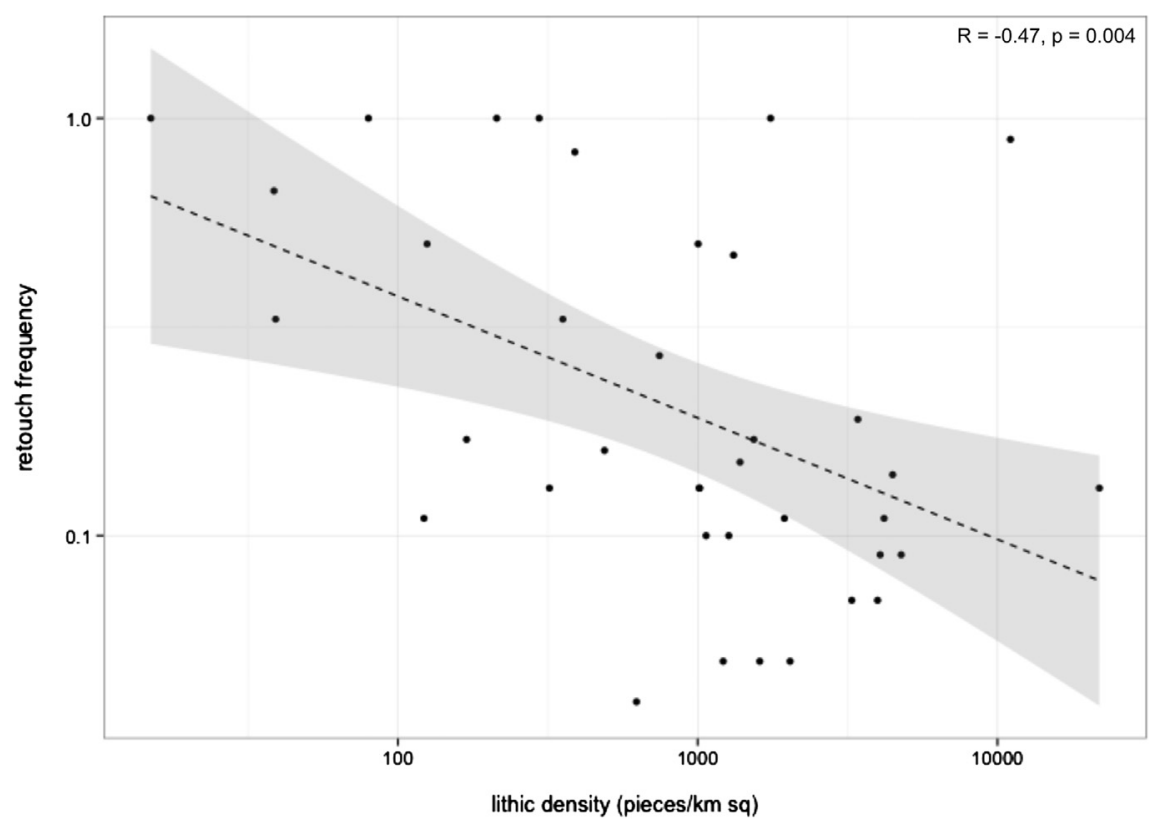

Fig. 5. Retouch frequency (retouched pieces/total lithics) for survey units with evidence of Upper Paleolithic use (Temporal Index $\geq 0.7$, see Barton et al., 1999, 2002). 


\section{Hunting strategies}

The relationship between the bones found in archaeological sites and animals hunted is far from direct. In addition to the palimpsests issues mentioned above are numerous other taphonomic considerations of differential preservation (or preservation at all) of faunal elements, field butchery, and social preferences for different taxa to name a few. These and other factors make it impossible to compare faunal remains in detail across all the assemblages of our sample-and exclude all survey collections entirely. However, we are able to calculate a herbivore index across most excavated samples, that is the ratio of large herbivores (artiodactyls and perissodactyls) to lagomorphs and large herbivores combined-normally calculated on the basis of NISP. This is similar to the artiodactyl index calculated for North American sites, which is the ratio of artiodactyls to lagomorphs plus artiodactyls (Broughton, 1984; Szuter and Bayham, 1989; Schollmeyer and Driver, 2012).

While hunting rabbits generally is taken to indicate a focus on local food resources on the basis of ethnographic studies as well as the energetics of hunting and processing rabbits relative to their caloric return, the herbivore ratio does not necessarily measure the importance of rabbits in the diet-which can vary for a variety of reasons including the availability of rabbits near camps and the availability of supplementary foods. More directly, the herbivore index is a measure of the processing of animal carcasses. That is, at hunting camps, the carcasses of large-bodied herbivores can be returned whole or in major sections to be cooked and butchered at the camp-leaving more of their bones in faunal assemblages. However, when large herbivores are taken during long-distance hunting trips, it is more likely they will be field processed and only the meat returned to base camps-leaving faunal remains dominated by small game whose carcasses will be returned whole (Lyman, 1979; Binford, 1981; Davidson, 1989).

\section{Relationships among proxies for ecological behaviors}

Given ethnographic accounts of recent forager ecological behaviors, we might expect that dominance of small game would be more prevalent in faunal remains at base camps associated with longer residence time, while higher herbivore index values should be found in contexts with lithic indicators of higher residential mobility. Similarly, specialized hunting technologies should be produced at base camps and field maintained at resource acquisition camps (Neeley and Barton, 1994). However, the by-products of the production of such specialized technologies (e.g., exhausted bladelet cores, tiny flakes from backing, small bone fragments from point and/or harpoon production) tend not to appear on standard artifact type lists, while the end products discarded during weapons maintenance are often classified as tools (e.g., broken or dulled backed bladelets, bone points, bone harpoons). Hence, we might also expect to find a correspondence between proxies for higher mobility camps and higher values of the technological specialization index. We might also, then, expect to find a transitive covariance between herbivore index and the technological specialization index.

These predictions are in fact borne out, as can be seen in Fig. 6 . There are strong, positive correlations between retouch frequency and herbivore index, and between retouch frequency and technology specialization index (Fig. 6A and B). (Because of the small sample size, variation in data recovery technique by different excavators, the simple nature of the indices, and the fact that different measures give results that are consistent with one another, alpha $=0.10$-that is, a $10 \%$ probability of mistakenly thinking that measured covariation is not due to chance alone-provides a sufficient level of confidence in the statistical trends discussed here (see Cowgill, 1977).) A similar trend can be seen for herbivore index versus technology specialization index (Fig. 6C) but it is not statistically significant. However, if two outlier assemblages (the Magdalenian assemblage at Cendres and Gravettian at Nerja, indicated by circles) are eliminated, the remaining assemblages show a strong positive correlation (Fig. 6D). That is, herbivore index and technological specialization index covary for most, but not all assemblages reported here. But there are no obvious characteristics of the two outlier assemblages to explain why they do not conform to the trend exhibited by the majority of assemblages.

This illustrates two important points. First, there are multiple factors that influence the composition of palimpsest discard assemblages at archaeological sites. Just because both a dominance of large herbivore faunal remains and elements from the field maintenance of specialized weapons tend to take place in contexts of higher mobility, there is no reason why large animal butchery and consumption needs to co-occur with the maintenance of these weapons. Second, while large numbers of artifacts are represented in this study, in fact the number of meaningful cases included (i.e., assemblages) is very small for studying regional-scale eco-dynamics, an issue we return to at the end of this paper. The small sample size can make it difficult to identify ecological or temporal trends and, as in the case of herbivore index and technology specialization index, one or two anomalous assemblages can significantly mask a statistical trend.

\section{Geographic variables}

While forager ecological behaviors can be affected by a variety of environmental parameters, there are no paleoenvironmental data available at sufficiently fine scale across the sampled sites to be useful for comparative analyses. Moreover, modern environmental conditions cannot be used as proxies for past ones. It may be possible to model aspects of past terrain and vegetation (e.g., Barton et al., 2010, 2012), but this work has not yet been done for this region and time frame. Still, there are several kinds of geographic data that can provide some indication of spatial variability in environmental context within which to analyze the archaeological data. For all sites and survey collection units, we measure elevation, shortest distance from the late Pleistocene coast, and latitude. We use coastlines determined by Pleistocene sea levels for calculating distance to the coast. While sea level fluctuated throughout the late Pleistocene, we use values of $-90 \mathrm{~m}$ at $30 \mathrm{ka}$ for pre-LGM sites, $-115 \mathrm{~m}$ at $18 \mathrm{ka}$ for LGM sites, and $-70 \mathrm{~m}$ at $13 \mathrm{ka}$ for post-LGM sites (Siddall et al., 2003) estimated from ETOPO2 ocean floor topography (NOAA, 2006). This does not take into account any neotectonic changes in coastal elevation, which are not sufficiently well known across the region. For elevation, we use modern elevation above mean sea level. While the elevation of sites above sea level varied along with Pleistocene sea level, their vertical positions relative to each other did not. Thus, modern elevation is a reasonable proxy.

\section{Results}

\subsection{Land-use strategies}

Retouch frequency shows negatively trending covariation with both elevation and distance from the Pleistocene coastlines, but these relationships are not statistically significant (Fig. 7A and B). In both cases, the relationships are strengthened and are statistically significant if the assemblages from the one site on the coast for the entire Pleistocene (Gorham's Cave) are not considered (Fig. 7C and D). This trend indicates that inland and higher elevation sites (these covary because elevation rises from sea level to the central Iberian 

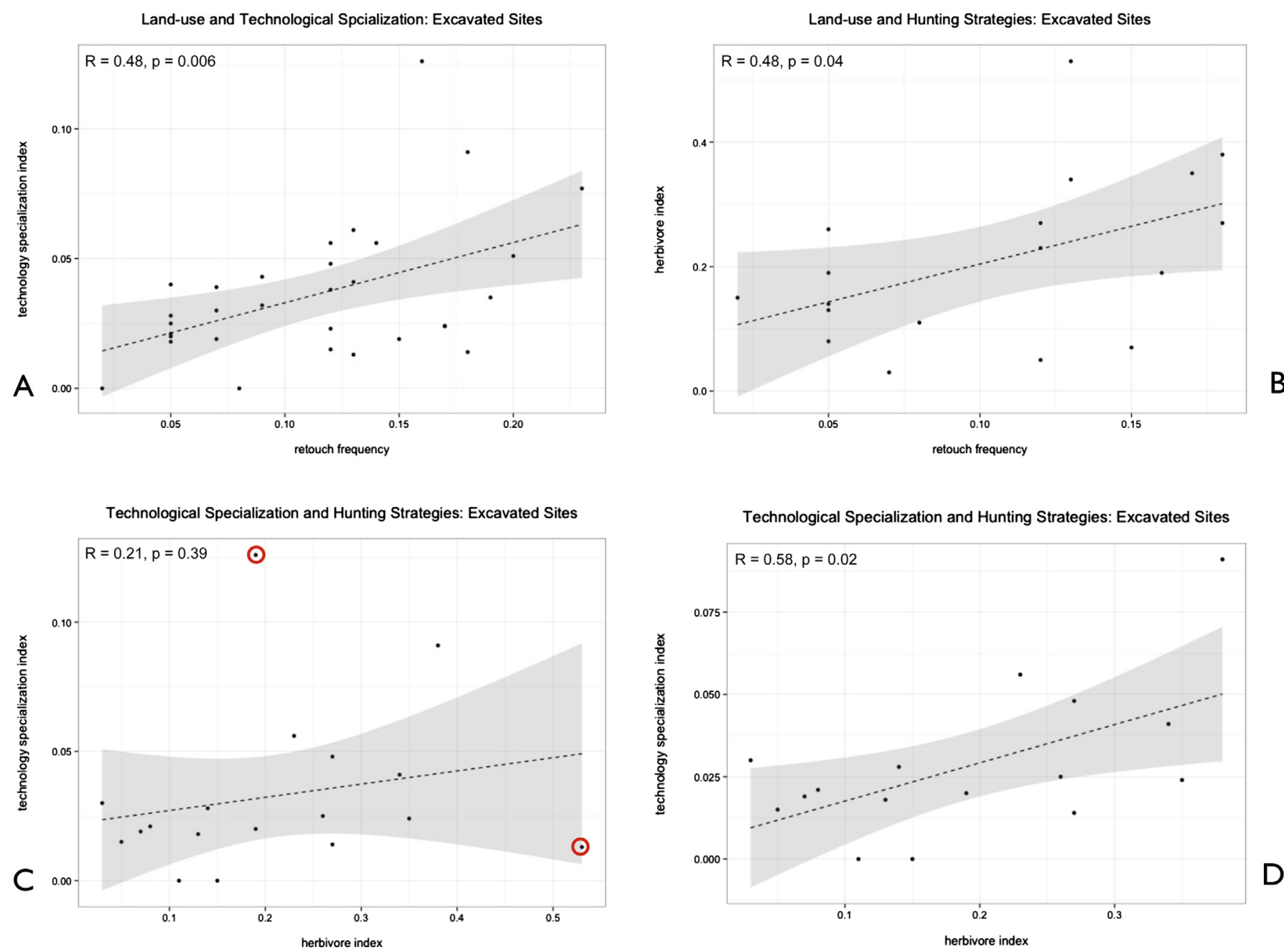

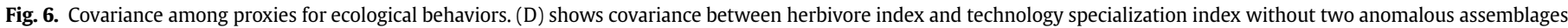
(see text for discussion) indicated by circles in (C).

Meseta in the Mediterranean region) are increasingly dominated by base-camp-like assemblages characterized by place provisioning and longer residence times. Lower elevation sites-but not coastal sites-are increasingly dominated by higher mobility, shorter residence times, and individual provisioning. It should be noted that overall land-use strategies for the Upper Paleolithic of this region are likely to be dominated by logistical organization (Barton et al., 2011; Barton and Riel-Salvatore, 2012) Hence, localities with short-term occupation are likely to be targeted resource foray camps rather than evidence for general residential mobility strategies.

While a positive relationship between land-use and elevation and distance to the coast holds for most assemblages, investigating the reason that coastal sites do not follow the same trend is informative. Several other sites are near the coast today, but local sea floor configurations mean that only Gorham's was also within $1 \mathrm{~km}$ of the coast at all times during the late Pleistocene, in spite of lowered sea level. There were certainly other sites on the Pleistocene coast, but these are now underwater and unavailable for study. Instead of attempting to fit a simple linear regression line to the data, we can fit a locally weighted regression (LOESS, locally estimated scatterplot smoothing, or LOWESS, locally weighted scatterplot smoothing) curve that can help to visualize more complex, non-linear relationships. These can be seen in Fig. 7E and F. The trend for increasing retouch frequencies in lower-elevation and more coastal sites can be seen clearly. But at elevations below
$250 \mathrm{~m}$ and locales within $10 \mathrm{~km}$ of the Mediterranean coast, this trend reverses and retouch frequencies decline downwards and towards the coast. Although there are only assemblages from one site in our sample that were located on the Pleistocene coast (although seven assemblages are from localities that were within $10 \mathrm{~km}$ ), the LOESS trend suggests that coastal sites in general could also be dominated by base-camp-like like occupations.

An identical and statistically robust trend can be seen for survey data (Figs. 8 and 9). Notably, retouch frequencies vary over a much wider range for survey collections than they do for the excavated cave and shelter sites, reinforcing the suggestion made above that these data capture some of the very small, short-term camps that are not as visible in excavated assemblages. The survey areas do not extend to the coast. But when rescaled and a LOESS fit is applied for comparison, they match the trend of the corresponding excavated sites for elevation (Fig. 9).

\subsection{Hunting strategies}

Hunting strategies, as indicated by herbivore index, follow a pattern very similar to that of land-use strategies (Fig. 10A-D). Herbivore index is significantly correlated with elevation and distance from the Pleistocene coast for assemblages from non-coastal sites. LOESS smoothing (Fig. 10E and F) also shows a trend of increasing herbivore index coastward and at lower elevations to 

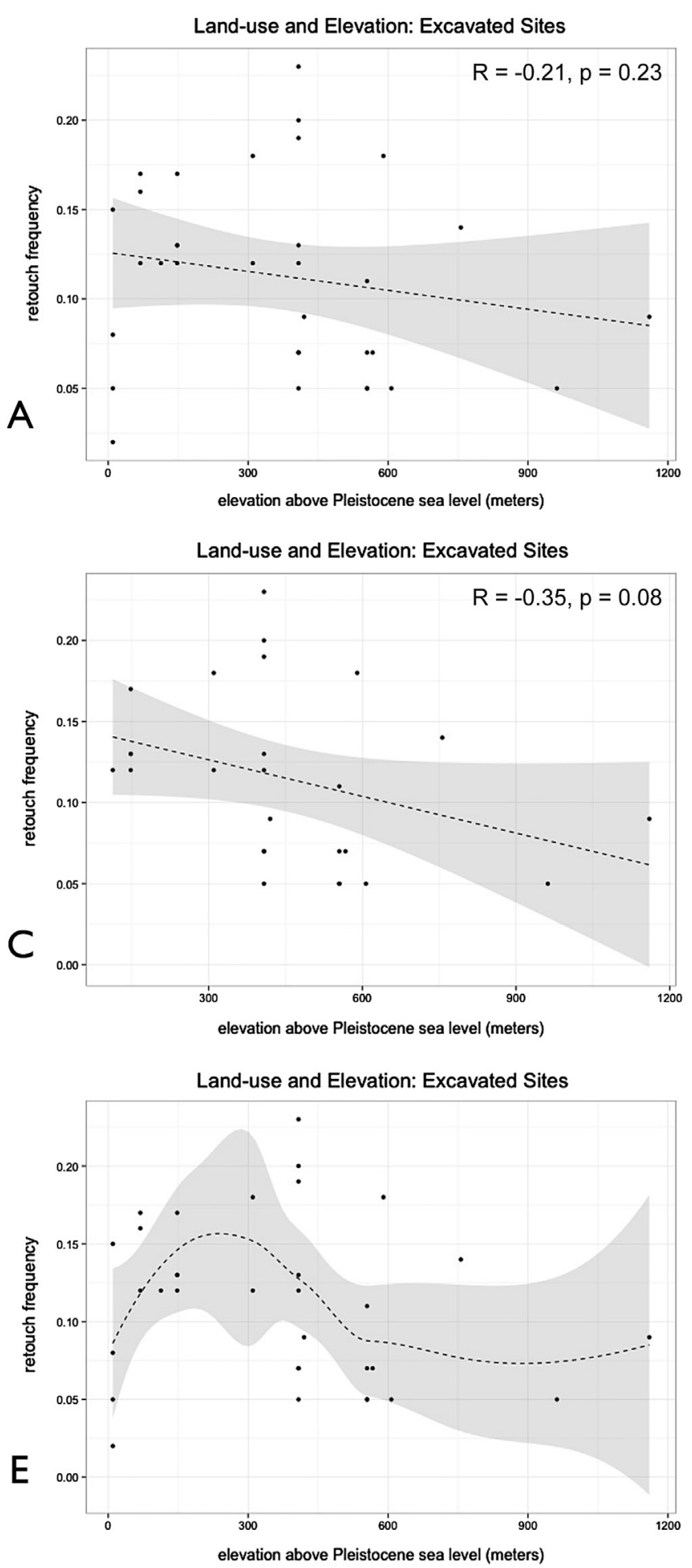

Land-use and Distance from Pleistocene Coast: Excavated Sites

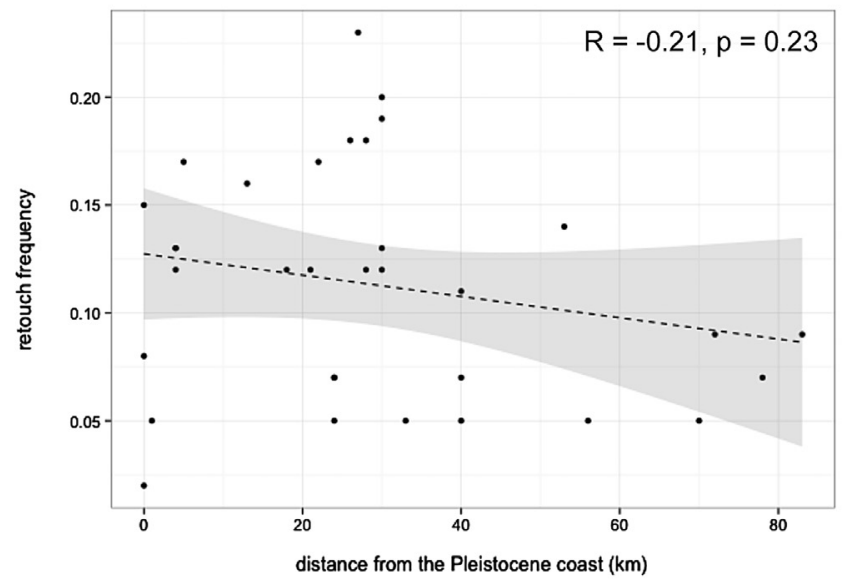

Land-use and Distance from Pleistocene Coast: Excavated Sites

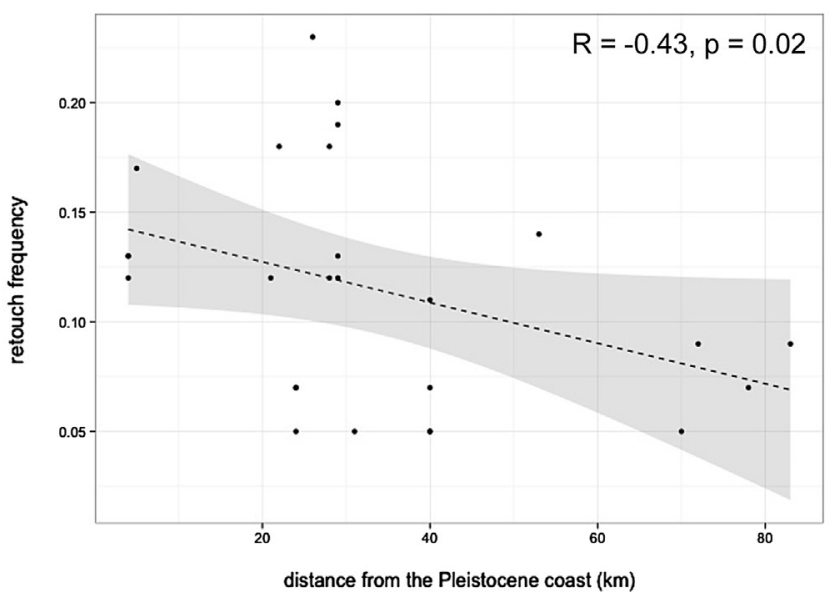

Land-use and Distance from Pleistocene Coast: Excavated Sites

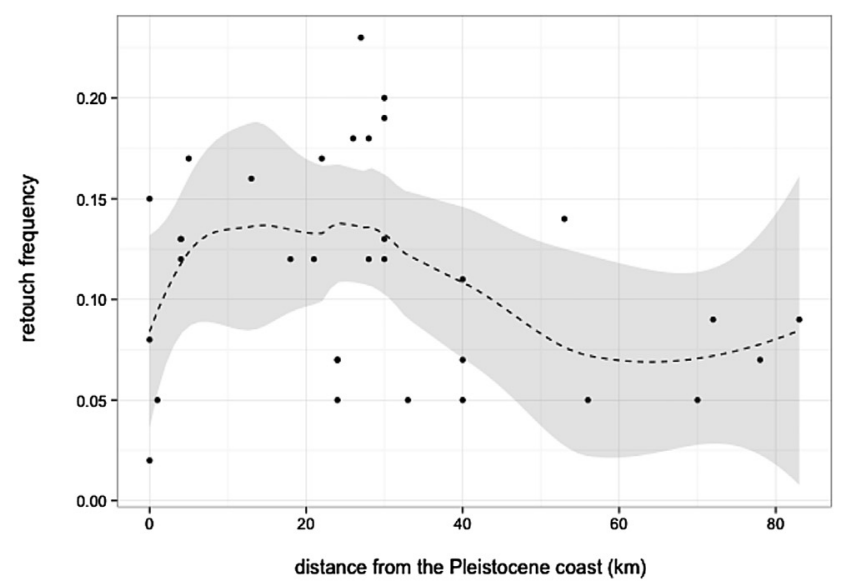

Fig. 7. Covariance among land-use proxy and elevation and shortest distance to the Pleistocene coast for assemblages from excavated sites. (A) and (B) are all Upper Paleolithic assemblages. Dashed line shows linear regression with $95 \%$ confidence intervals shown in grey shading. (C) and (D) show all Upper Paleolithic assemblages except for those from within $1 \mathrm{~km}$ of the Pleistocene coastline contemporaneous with the assemblage date. (E) and (F) show all Upper Paleolithic assemblages and LOESS curves with 95\% confidence intervals (see text). Pleistocene coast for pre-LGM assemblages (Aurignacian and Gravettian) are calculated for marine regression of $70 \mathrm{~m}$ below modern sea level; Pleistocene coast for LGM assemblages (Solutrean) are calculated at $115 \mathrm{~m}$ below modern sea level; Pleistocene coast for post-LGM assemblages (Magdalenian) are calculated at $70 \mathrm{~m}$ below modern sea level. Shortest distance to coast calculated using GRASS GIS. Elevations are elevations in meters above mean modern sea level.

about $10 \mathrm{~km}$ from the coast and $250 \mathrm{~m}$ in elevation, after which it declines seaward and with elevation.

Together with the parallel results from the analysis of land-use, this indicates a pattern in which base camps dominate occupations at elevations above $500 \mathrm{~m}$ and inland $50 \mathrm{~km}$ or more from the
Pleistocene coast, with the possibility of another set of base camps along the coast. Local, small game remains dominate the faunal assemblages of both sets of base camps. Between the two base camp zones, is a comparatively narrow ecozone at 5-20 km inland and $100-250 \mathrm{~m}$ in elevation is dominated by residues of short-term 


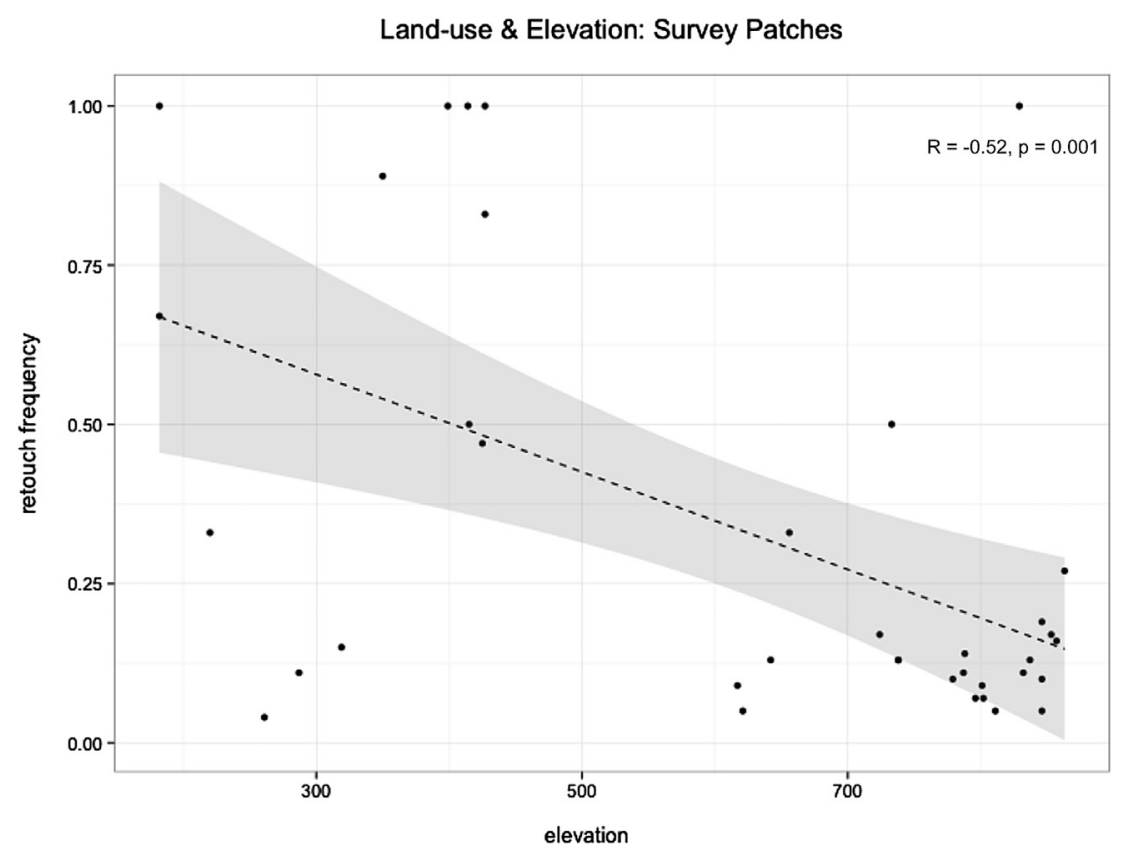

Fig. 8. Covariance between land-use proxy and elevation for assemblages from survey units with evidence of Upper Paleolithic use.

camps from which Upper Paleolithic hunters pursued and processed larger herbivores. It is possible that another zone of specialized hunting existed in the opposite direction from the inland base camp zone on the fringes of the Meseta, but we lack the archaeological data to test this hypothesis.

\subsection{Specialized technologies}

While the maintenance of specialized hunting weapons (technology specialization index) is associated with evidence of shortterm camps and the processing of large herbivores, it does not covary significantly with either elevation or distance from the coast (but does exhibit a pronounced peak in the zone $10-30 \mathrm{~km}$ from the coast when a LOESS curve is fit to the data). That is, while landuse and hunting practices are associated with ecological contexts, weapon maintenance is associated with particular human behaviors rather than the landscape itself.

However, while both land-use and hunting strategies do not show any time trends across the Upper Paleolithic, specialized hunting technologies become increasingly prevalent during this time (see below). In traditional typological analysis, this is seen in the increasing importance of microlithic elements and bone artifacts from the Aurignacian through the Magdalenian. It is not clear what is driving this vectored changed in technology. The increase in specialized hunting weaponry may be in part a response to increasing population and decreasing large game, requiring increasingly longer hunting forays and the need to decrease the risk of hunting failure through investment in weapons technology.

\subsection{Temporal dynamics}

The lack of significant change in Upper Paleolithic eco-dynamics across the Mediterranean region of Iberia is apparent in Fig. 11. There may be slight increases in logistical land-use and large herbivore hunting associated with the LGM, but the only statistically significant time trend is the increased use of specialized hunting weapons mentioned above. Even taking into account the small sample sizes, the amount of change throughout the late Pleistocene seems limited, especially in comparison with the Holocene assemblages included for comparison here.

This apparent long-term stability in human ecology over a span of $20 \mathrm{ky}$ is notable, considering the amount of environmental change experienced in glaciated terrains to the north. While not affected in the same ways as the environments of glacial Europe, the Iberian Peninsula did experience environmental change over this time span, as noted above. However, human socio-ecological systems appear to have been sufficiently flexible and resilient to be sustained with little apparent change.

The vectored change in specialized weapons does not seem to correspond with large-scale environmental shifts associated with the LGM, but rather is a continuous trend throughout the late Pleistocene. As noted above, it may be more a response to changes in human-constructed niches than climate-driven environmental shifts.

\subsection{Variation with latitude}

None of the proxies for Upper Paleolithic ecological behaviors exhibited statistically significant or even visible trends with latitude. That is, there is no evidence that the overall organization of human eco-dynamics varied from north to south across Mediterranean Spain, in spite of existence of glacial environments north of the Pyrenees and an apparent south to north shift in the composition of late Pleistocene forests within the Mediterranean zone. Rather, the most notable patterns of variation were along the axis inland from the coast. However, the nature of the sample of sites with assemblages available for study may be affecting these results. Considerably more Pleistocene coastal plane was exposed in northern Mediterranean Spain than in the south (Fig. 12) and consequently the available sample is increasingly deficient in coastal and near-coastal sites as one proceeds from south to north.

\section{Discussion}

In order to study the eco-dynamics-i.e., spatial/temporal change in human socio-ecological systems-of late Pleistocene 

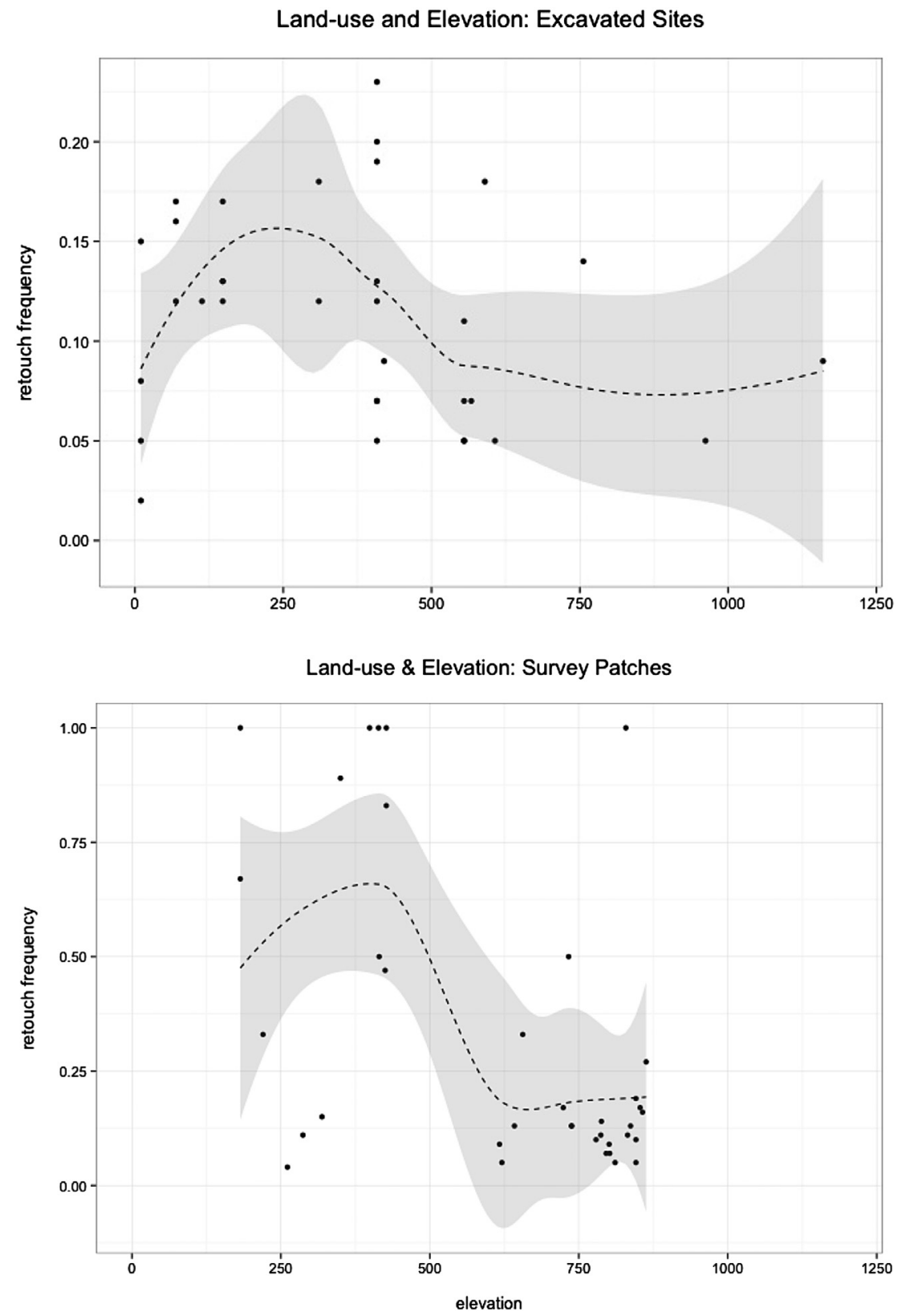

Fig. 9. Comparison of land-use proxy and elevation, with LOESS curves and $97 \%$ confidence intervals, for excavated and survey assemblages.

foragers in Mediterranean Spain, we have synthesized data from numerous archaeological assemblages recovered from across this very broad region. Rather than take the more traditional approach of crafting a narration from largely intuitive interpretations of selected features of each of these assemblages, we have devised a set of theory-based, quantitative measures of several key dimensions of hunter-gatherer ecological behaviors: land-use strategies (encompassing mobility and settlement), hunting strategies (spanning multiple dimensions of prey size, acquisition, and processing), and technology (focusing primarily on hunting technology, but also involving technological specialization and labor investment). We also proposed on the basis of ecological theory that these indices, calculated from assemblage-scale archaeological data, should covary in particular ways-and they met these expectations in the data available for study here, providing statistical support for their reliability as proxies for ancient ecological behaviors. There are other equally important dimensions to be sure, including social organization and information transmission, and niche construction, but the suite of behaviors we monitored are more directly accessible from the available archaeological record-and are also fundamental to human fitness.

This approach provided new opportunities to examine relationships between ancient ecological behavior and environmental variation in space and time. It also offers a new, holistic perspective on the organization of Paleolithic hunter-gatherer societies-and one that is supported by robust quantitative data. At the same time, the results of this research are not at odds with prior research that has inferred the dynamics of Upper Paleolithic socio-ecological systems on the basis of more limited evidence (Villaverde Bonilla et al., 1999; Aura Tortosa et al., 2010), but rather provides rigorous support for this work and helps to situate it in a broader regional context.

Analyses of spatial and temporal variation in proxies for landuse strategies, hunting strategies, and technological specialization 


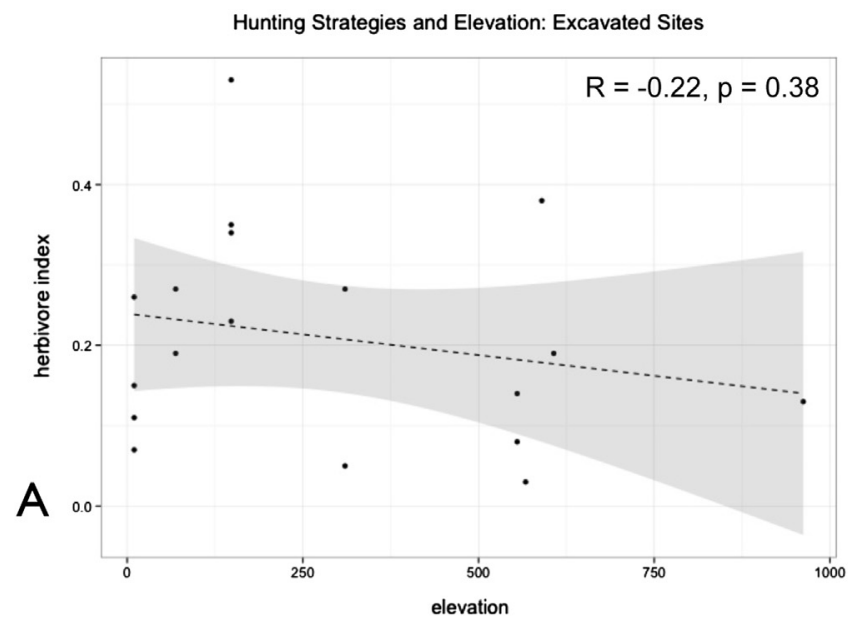

Hunting Strategies and Distance from Pleistocene Coast: Excavated Sites
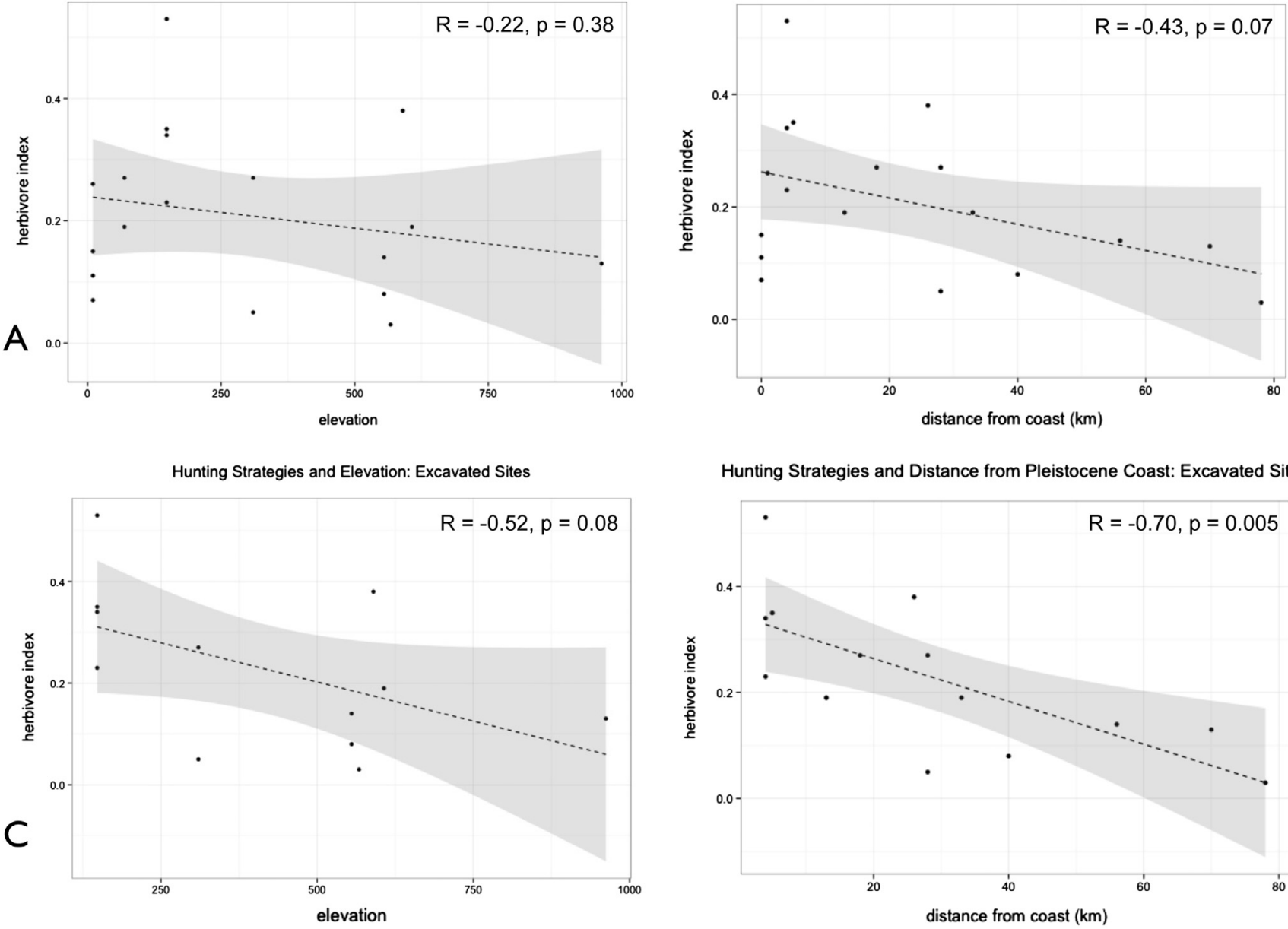

Hunting Strategies and Distance from Pleistocene Coast: Excavated Sites

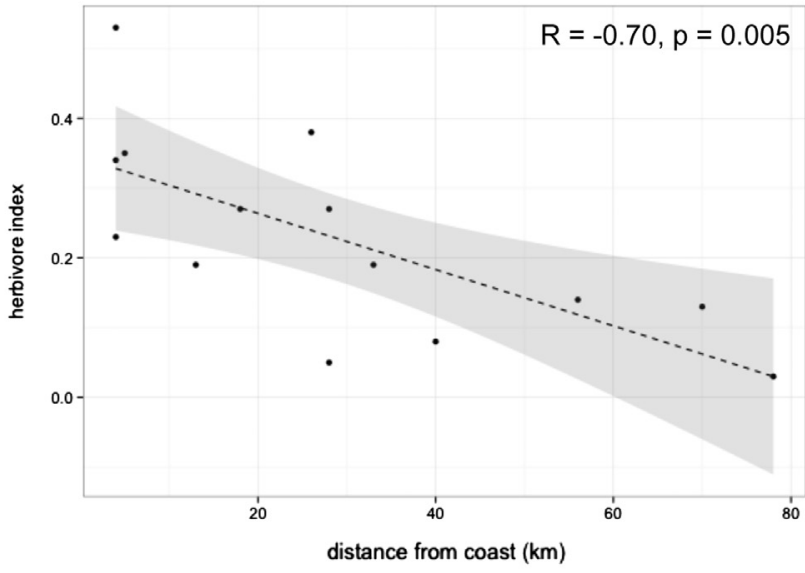

$\mathrm{D}$

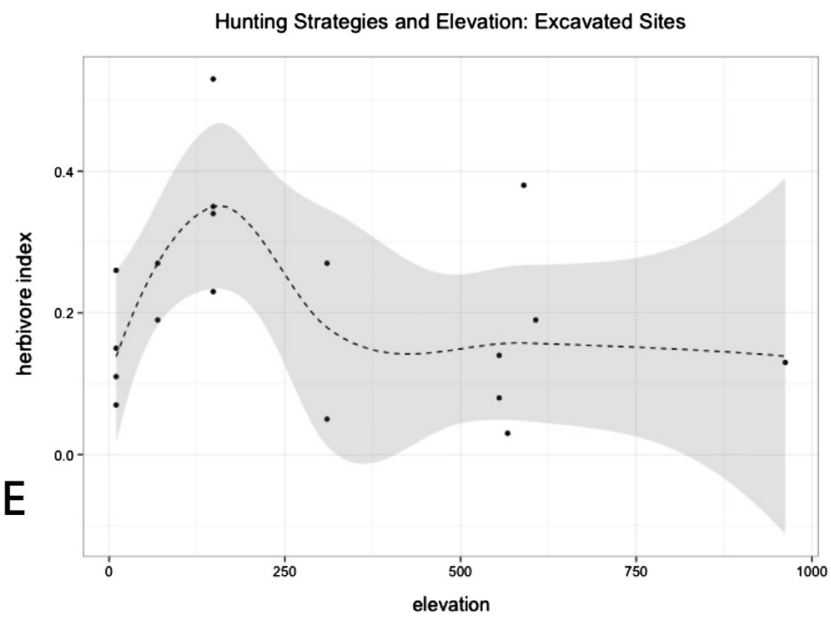

Hunting Strategies and Distance from Pleistocene Coast: Excavated Sites

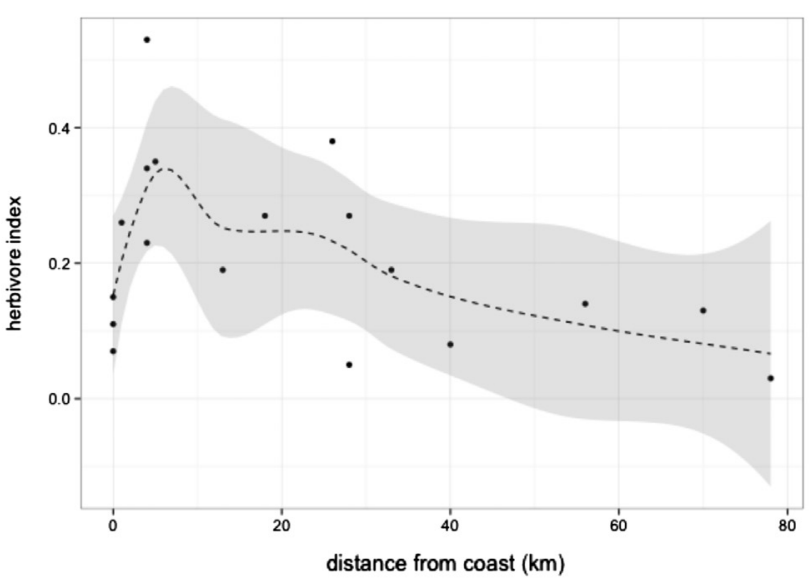

Fig. 10. Covariance among hunting strategies proxy and elevation and distance from the Pleistocene coast for assemblages from excavated sites. (A) and (B) are all Upper Paleolithic assemblages. Dashed line shows linear regression with $95 \%$ confidence intervals shown in grey shading. (C) and (D) show all Upper Paleolithic assemblages except for those from within $1 \mathrm{~km}$ of the Pleistocene coastline contemporaneous with the assemblage date. (E) and (F) show all Upper Paleolithic assemblages and LOESS curves with 95\% confidence intervals.

indicates that Upper Paleolithic settlement and subsistence systems were anchored by base camps, located at inland locations 50 $100 \mathrm{~km}$ from the Pleistocene coastline (i.e., with lowered sea level) and elevations intermediate between the coast and central Meseta. These base camps were occupied and/or reoccupied for sufficient duration to encourage place provisioning. Hunting at these base camps produced faunal assemblages dominated by local, small game-especially rabbits. This is probably a result of large game being field-processed at distant hunting/butchering sites (leaving most bones behind) before being returned to base camps for consumption. However, rabbits bones also may be more common in base camps because longer-term occupations depleted large game 

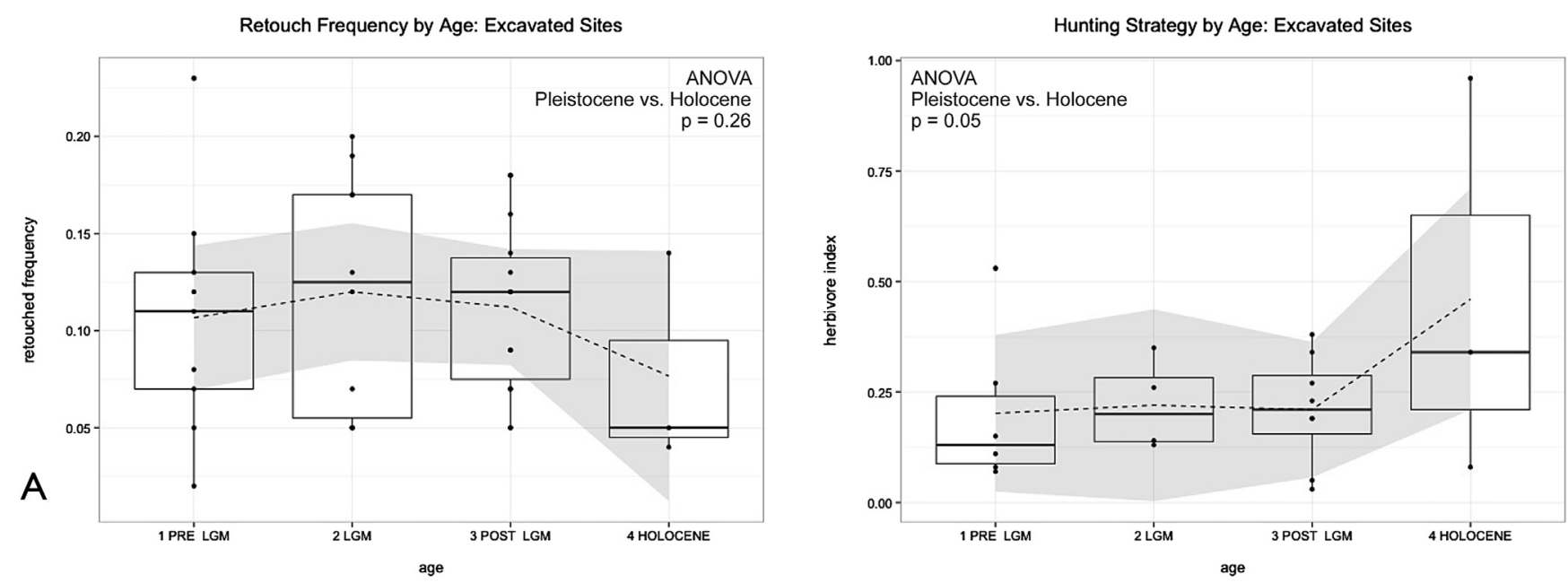

B
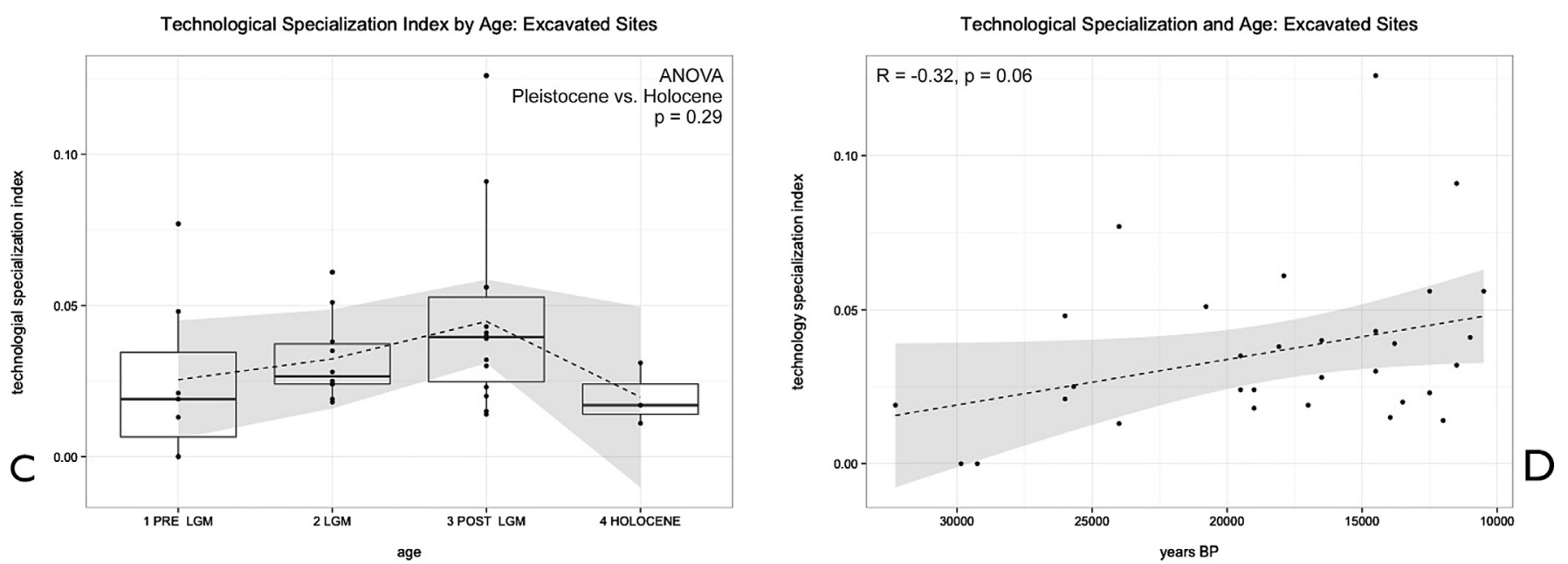

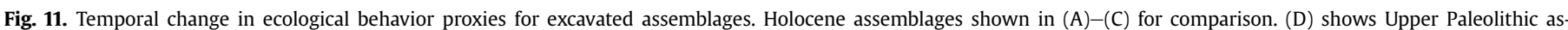

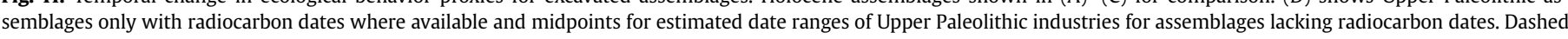
line shows linear regression and grey shading indicates $95 \%$ confidence interval.

Width of Pleistocene Coastal Plane Lost: Excavated Sites

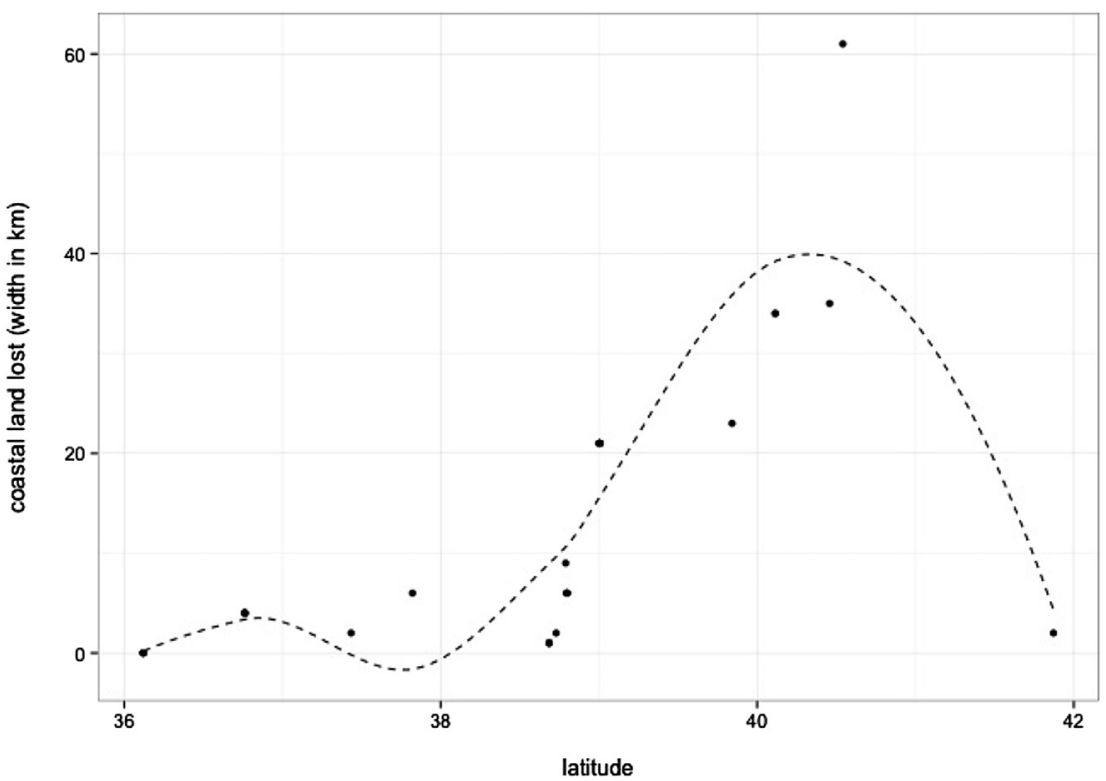

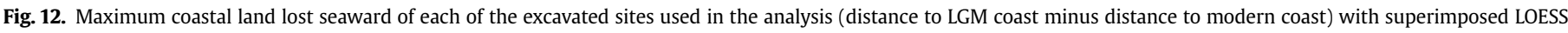
curve (dashed line). 
in the immediate vicinity of these sites. Unfortunately, it is not yet possible to disentangle these related but different ecological processes on the basis of available evidence. Another set of base camps may have been located adjacent to the Pleistocene coast, most of which were inundated by rising sea levels.

Between the inland base camps and the coast was a zone in which large herbivores were hunted by small groups who butchered these animals and repaired specialized-portable, reliable, and field-maintainable-hunting weapons in short-term camps. The inland base camps could potentially have used another hunting zone $30-50 \mathrm{~km}$ further inland, at the border of the Meseta, although we currently lack relevant archaeological data to test this. If this is the case and Upper Paleolithic sites are discovered in this region, they should be characterized by relatively high values of retouch frequency, herbivore index, and technology specialization index as described here. However, there may also have been differences in hunting patterns given environmental differences between the colder Meseta and more mesic uplands nearer the coast.

Once established in the early Upper Paleolithic, this resilient pattern of landscape and resource use was apparently maintained for another 20 ka throughout Mediterranean Spain, until the end of the Pleistocene. Importantly, this stable way of life extends in time across traditional classifications of Upper Paleolithic industries. The one area of apparent temporal change is in the increasing importance of specialized hunting weapons-possibly the underlying driver of the changes in archaeological materials that are classified as late Aurignacian, Gravettian, Solutrean, and Magdalenian. Because this vectored change in technology shows a consistent trend throughout the Upper Paleolithic and because it does not seem to covary with climate-driven environmental changes, at least at a coarse resolution, it may be a response to anthropogenic eco-dynamics. This suggestion is purely circumstantial with respect to available empirical evidence, but warrants testing in the future.

\section{Concluding thoughts and future directions}

In comparison with much Paleolithic research, this study synthesizes a large data set to gain new insights into regional-scale eco-dynamics. In reality, however, our data set is very small, both in terms of the locales used by Paleolithic foragers over $20 \mathrm{ka}$ across Mediterranean Spain and to carry out the kinds of analyses we employ here. To gain some perspective on representativeness of the excavated materials analyzed here, we only have to compare it with the surface collections. Materials from 37 excavated Upper Paleolithic assemblages were studied, recovered from 16 sites spread across Mediterranean Spain, and representing nearly all the completely analyzed Upper Paleolithic assemblages from this region available at the time of writing. The 417 surface collection units represent well under half the areas of five modest valleys from the central Valencian Region alone-a tiny fraction of the area of Mediterranean Spain. Yet they include 37 units with Upper Paleolithic artifacts-equal to all available excavated assemblages from the entire Mediterranean region. Moreover, a very large amount of land of Pleistocene Mediterranean Spain now lies beneath the sea, especially in the northern part of this region (Figs. 3 and 12). Both of these factors likely bias the available sample in unknown ways. The small sample size also makes much more difficult the identification and statistical confirmation of covariance and trends in time and space.

Characterization of the spatial and temporal dynamics of human socio-ecological systems and their environmental contexts is essential to understanding the drivers of coupled biological and cultural evolution. However, a serious research program on Pleistocene human eco-dynamics requires a commitment to considerable reorientation of the practice of Paleolithic archaeology. This involves the kinds of data collected, the way they are collected, and the way they are analyzed as well as an emphasis on the development and testing of explicit, theory-based (and to the extent possible quantitative) models rather than inductive and intuitive narratives.

It is common for regional syntheses like this one to call for additional fieldwork. The fact that only 16 sites represent nearly all the available excavated assemblages for $20 \mathrm{ka}$ of human prehistory for the entire region of Mediterranean Spain justifies such a call. However, numerous other known sites date to this period in the region and many have been excavated. But the collections recovered from these sites have either not been analyzed, or have not been analyzed completely and quantitatively, or the analyses have not been published or otherwise been made available to the scientific community. Analyzing existing collections and making the data available (preferably in digital form) can significantly increase the sample size for the kind of study illustrated here.

Moreover, the fact that less than a dozen seasons of systematic, patch-based survey in a small part of this larger region produced significantly more (and perhaps more representative) Upper Paleolithic assemblages than decades of excavation at the 16 sites suggests that it would be wise to diversify the ways in which the archaeological record is sampled. Caves and rock shelters are convenient places to carry out Paleolithic archaeology, but were such rare and special places on the landscape that they almost certainly do not represent the normal range of human activities and land-use. Additionally, while surface collections have limitations in the kinds of chronological methods that can be applied and for the preservation of non-lithic materials, cave and shelter sites also suffer from the accumulation of dense, time-averaged palimpsests, artifact damage and reuse, and vertical mixing that can leave chronological frameworks as uncertain as those of surface collections (Barton and Clark, 1993; Farrand, 1993; Bernabeu et al., 2001). For any such work, it is imperative that it be carried out with statistically valid sampling designs, and that data collection methods be implemented to maximize the systematic recovery of materials needed for eco-dynamics research.

Research on human eco-dynamics also will benefit from new kinds of data, like stable isotope analysis of animal and human bones, and chemical analysis of residues on stone artifacts. But even more important is new, theory driven, quantitative analyses of the collections that already reside in museums and university repositories. It will be essential, however, that such analyses either make complete counts or statistically valid samples of archaeological materials rather than only listing retouched "tools", illustrating "typical" artifact forms (which are never statistically typical), or identifying selected faunal taxa as present or absent. The work presented here offers a theoretical basis for some kinds of very simple, but potentially informative, quantitative analyses. But there are other, equally valuable, theory-based analytical protocols for eco-dynamics that can guide new work on existing but minimally studied collections. Examples for lithics include estimations of cortex removal, measures of flake reduction, and comparisons of complete and truncated reduction sequences (chaîne opératoires) to name but a few (Kuhn, 1994; Morrow, 1996; Dibble et al., 2005; Douglas et al., 2008; Riel-Salvatore and Negrino, 2009). The results of these studies, along with the current one, emphasize the value of quantitative, whole-assemblage analyses over studies of individual artifacts for understanding human ecological systems at the regional scale in which they operated.

Equally important is the need for additional, high resolution paleoenvironmental data. But even more so is the need for synthesis in spatially explicit format of the diverse kinds of paleoenvironmental data that currently exist. Archaeological excavations at many Paleolithic sites have been accompanied by sedimentary 
analyses, and the collection of samples of pollen, charcoal, and fauna-and some have enjoyed even more sophisticated paleoenvironmental study. But these data by and large are buried in the backs of excavation reports or published in diverse natural science journals. The Stage Three Project (van Van Andel, 2002) was a laudable endeavor to synthesize diverse paleoenvironmental data for a particular time period in Europe; similar efforts should be initiated for other times and places. A variety of computational modeling approaches are particularly useful for synthesizing proxy data and representing the dynamics of Pleistocene environmental change. Examples include different approaches to modeling climate, vegetation, and landscape change (Ruter et al., 2004; Clevis et al., 2006; Phillips and Dudík, 2008; Liu et al., 2009; Barton et al., 2010; McDonald and Bryson, 2010; Voinov et al., 2010).

In closing, we want to emphasize that the scenario of late Pleistocene eco-dynamics in the Mediterranean facade of the Iberian Peninsula we present here is a model derived from theorybased analyses of empirical archaeological data from this region. It now needs to be tested. But because it is an empirically derived model, it cannot be tested against the data on which it is based; new data are required for testing. However, this model of Upper Paleolithic ecological organization and change offers several clear predictions that can guide testing and future refinement.

To the extent that they were integrated into the Mediterranean socio-ecological system, sites along and below the western edge of the Meseta should have evidence of short term use and individual provisioning (relatively higher retouch frequencies), a dominance of large-bodied animals remains (higher herbivore index), and maintenance of specialized and portable hunting weapons (higher technology specialization index). Sites that are located along the Pleistocene coast are more likely to have survived marine transgression in the southern part of the region than in the north. These sites should tend to appear more like base camps with evidence of longer residence times and place provisioning (higher retouch frequencies). Their fauna should also be dominated by local taxa, but these may include shellfish, fish, and marine mammals as well as (or perhaps instead of) rabbits and other small game. Technological specialization index does not covary with distance from the coast, and so may vary in value within coastal assemblages. But careful analysis of assemblages with base-camp characteristics (in coastal or inland locations) should reveal the more subtle evidence of the manufacture of specialized hunting weapons (Aura Tortosa et al., 2010; Villaverde Bonilla et al., 2010; Borao Álvarez, 2013). More detailed analyses of fauna-including butchery and skeletal element analyses and stable isotope analysis-should show that large herbivores whose remains are found at short-term hunting camps tend to be locally killed and butchered, while those in base camps should show evidence of transport into the sites. Finally, intensive, patch-based survey-especially in the large game hunting zone between the inland and coastal base camps-should reveal the presence of short-term camp residues in the form of lithic collection of low artifact density per unit area but high retouch frequencies. We hope that the work presented here encourages further research applying ecological theory and perspectives to human evolution.

\section{Acknowledgements}

We want to thank Jonathan Haws and Nuno Bicho for organizing the symposium at the Society for American Archaeology meetings (2012) that stimulated this synthesis and for compiling this special issue of Quaternary International. This research was supported in part by the National Science Foundation (USA) grants BNS-9115209, SBR-9904050, BCS-0075292, and BCS-0331583; a Fulbright Senior Research Fellowship from the Committee for the International
Exchange of Scholars; and Ministry of Science and Innovation (Spain) projects FFI2008-01200/FISO, CGL2009-06988, HAR200803005, HAR2011-24878, and HAR2012-33111.

\section{Appendix A. Supplementary data}

Supplementary data related to this article can be found at http:// dx.doi.org/10.1016/j.quaint.2013.05.007.

\section{References}

Aura, J.E., Pérez-Ripoll, M., 1995. El Holoceno inicial en el Mediterráneo español (11.000-7.000 BP). Características culturales y económicas. In: Villaverde, V. (Ed.), Los últimos cazadores. Transformaciones culturales y económicas durante el Tardiglaciar y el inicio del Holoceno en el ámbito mediterráneo. Instituto de Cultura Juan Gil-Albert, Diputación Prov. de Alicante, Alicante, pp. 119-146.

Aura Tortosa, J.E., 2001. Los cazadores emboscados. El Epipaleolítico en el País Valenciano. In: Villaverde Bonilla, V. (Ed.), De Neandertales a Cromañones. Los inicios del poblamiento humano en el País Valenciano. Universitat de València, Valencia, pp. 219-238.

Aura Tortosa, J.E., Villaverde, V., González Morales, M., González Sainz, C., Zilhão, J. Straus, L.G., 1998. The Pleistocene-Holocene transition in the Iberian Peninsula: continuity and change in human adaptations. Quaternary International 49/50, 87-103.

Aura Tortosa, J.E., Jordá Pardo, J.F., Pérez Ripoll, M., Rodrigo García, M., Badal Garcia, E., Guillem Calatayud, P., 2002a. The far south: the Pleistocene-Holocene transition in Nerja Cave (Andalucía, Spain). Quaternary International 9394, 19-30. http://dx.doi.org/10.1016/S1040-6182(02)00004-6.

Aura Tortosa, J.E., Villaverde Bonilla, V., Pérez Ripoll, M., Martínez Valle, R., Guillem Calatayud, P.M., 2002b. Big game and small prey: Paleolithic and Epipaleolithic economy from Valencia (Spain). Journal of Archaeological Method and Theory 9, 215-268.

Aura Tortosa, J.E., Carrión Marco, Y., García Puchol, O., Jardón Giner, P., Jordá Pardo, J.F., Verdasco Cebrián, C., Morales Pérez, J.V., Pascual Benito, J.L., Pérez Jordà, G., Pérez Ripoll, M., 2006. Epipaleolítico-Mesolítico en las comarcas centrales valencianas. In: Alday Ruiz, A. (Ed.), El mesolítico de muescas y denticulados en la cuenca del Ebro y el litoral mediterráneo peninsular, pp. 65120. Vitoria-Gasteiz, Spain.

Aura Tortosa, J.E., Jordá Pardo, J.F., Morales Pérez, J.V., Pérez Ripoll, M., Villalba, M.P., Alcover, J.A., 2009. Economic Transitions in Finis Terra: the Western Mediterranean of Iberia, 15-7 ka BP. Before Farming Article 4.

Aura Tortosa, J.E., Jordá Pardo, J.F., Pérez Ripoll, M., Badal Garcia, E., Morales Pérez, J.V. Avezuela Aristu, B., Tiffagom, M., Jardón Giner, P., 2010. Treinta años de investigación sobre el Paleolítico Superior en Andalucía: La Cueva de Nerja (Málaga, España). In: Mangado Llach, J. (Ed.), El Paleolítico superior peninsular: novedades del siglo XXI: [homenaje al profesor Javier Fortea]. SERP, Barcelona, pp. 149-172.

Aura Tortosa, J.E., Tiffagom, M., Jordá Pardo, J.F., Duarte, E., Fernández de la Vega, J. Santamaria, D., de la Rasilla, M., Vadillo, M., Perez Ripoll, M., 2012. The Solutrean-Magdalenian transition: a view from Iberia. Quaternary International 272-273, 75-87. http://dx.doi.org/10.1016/j.quaint.2012.05.020.

Badal Garcia, E., 1998. El interés económico del pino piñonero para los habitantes de la Cueva de Nerja. In: Las culturas del Pleistoceno Superior en Andalucía. Patronato Cueva de Nerja, Málaga, Spain, pp. 287-300.

Barton, C.M., 1988. Lithic Variability and Middle Paleolithic Behavior: New Evidence from the Iberian Peninsula. British Archaeological Reports, Oxford.

Barton, C.M., 1998. Looking back from the world's end: Paleolithic settlement and mobility at Gibraltar. In: Sanchidrián Torti, J.L., Simón Vallejo, M.D. (Eds.), Las culturas del Pleistoceno superior en Andalucía. Patronato de la Cueva de Nerja, Nerja, pp. 13-23.

Barton, C.M., Clark, G.A., 1993. Cultural and natural formation processes in late Quaternary cave and rockshelter sites of western Europe and the Near East. In: Goldberg, P., Nash, D.T., Petraglia, M.D. (Eds.), Formation Processes in Archaeological Context. Prehistory Press, Madison, WI., pp. 33-52.

Barton, C.M., Riel-Salvatore, J., 2012. Agents of change: modeling biocultural evolution in Upper Pleistocene western Eurasia. Advances in Complex Systems 15, 1150003-1-1150003-24. http://dx.doi.org/10.1142/S0219525911003359.

Barton, C.M., Bernabeu Aubán, J., Aura Tortosa, J.E., Garcia Puchol, O., 1999. Landscape dynamics and socioeconomic change: an example from the Polop Alto valley. American Antiquity 64, 609-634.

Barton, C.M., Bernabeu Aubán, J., Aura Tortosa, J.E., Garcia, O., La Roca, N., 2002 Dynamic landscapes, artifact taphonomy, and landuse modeling in the western Mediterranean. Geoarchaeology 17, 155-190.

Barton, C.M., Bernabeu Auban, J., Garcia Puchol, O., Schmich, S., Molina Balaguer, L., 2004. Long-term socioecology and contingent landscapes. Journal of Archaeological Method and Theory 11, 253-295.

Barton, C.M., Ullah, I.I.T., Mitasova, H., 2010. Computational modeling and Neolithic socioecological dynamics: a case study from southwest Asia. American Antiquity $75,364-386$.

Barton, C.M., Riel-Salvatore, J., Anderies, J.M., Popescu, G., 2011. Modeling human ecodynamics and biocultural interactions in the late Pleistocene of Western Eurasia. Human Ecology. http://dx.doi.org/10.1007/s10745-011-9433-8. 
Barton, C.M., Ullah, I.I.T., Bergin, S.M., Mitasova, H., Sarjoughian, H., 2012. Looking for the future in the past: long-term change in socioecological systems. Ecological Modelling 241, 42-53. http://dx.doi.org/10.1016/j.ecolmodel.2012.02.010.

Bernabeu Aubán, J., Barton, C.M., Garcia, O., La Roca, N., 1999. Prospecciones sistemáticas en el valle del Alcoi (Alicante): primeros resultados. Arqueología Espacial 21, 29-64.

Bernabeu, J., Barton, C.M., Garcia, O., La Roca, N., 2000. Systematic survey in Alicante, Spain: first results. Türkyie Bilimer Akademisi Arkeoloji Dergisi 3, $57-86$

Bernabeu, J., Barton, C.M., Perez Ripoll, M., 2001. A taphonomic perspective on Neolithic beginnings: theory, interpretation, and empirical data in the western Mediterranean. Journal of Archaeological Science 28, 597-612.

Binford, L.R., 1980. Willow smoke and dogs' tails: hunter-gatherer settlement systems and archaeological site formation. American Antiquity 45, 4-20.

Binford, L.R., 1981. Bones: Ancient Man and Modern Myth. Academic Press, New York.

Borao Álvarez, M.I., 2013. Estudio tecnológico de los útiles fabricados sobre asta y hueso en el Magdaleniense Superior de la Cova de les Cendres (Teulada-Moraira, Alicante). SAGVNTVM. Papeles del Laboratorio de Arqueología de Valencia 44 http://dx.doi.org/10.7203/SAGVNTVM.44.1653. http://ojs/index.php/saguntum/ article/view/1653.

Broughton, J.M., 1984. Late Holocene resource intensification in the Sacramento Valley, California: the vertebrate evidence. Journal of Archaeological Science 21, 501-514.

Cacho Quesada, C., Fumanal, M.P., López, P., López, J.A., Pérez, R., Martínez Valle, R. Uzquiano, P., Arnanz, A., Sanchez Marco, A., Sevilla, P., Morales, A., Roselló, E. Garralda, M.D., García Carrillo, M., 1995. El Tossal de la Roca (Vall d’Alcalà, Alicante). Reconstrucción paleoambiental y cultural del Tardiglaciar al Holoceno inicial. Recerques del Museu d'Alcoi 4, 11-102.

Carbonell, E., Bermudez de Castro, J.M., Pares, J.M., Perez-Gonzalez, A., CuencaBescos, G., Olle, A., Mosquera, M., Huguet, R., van der Made, J., Rosas, A., Sala, R. Vallverdu, J., Garcia, N., Granger, D.E., Martinon-Torres, M., Rodriguez, X.P. Stock, G.M., Verges, J.M., Allue, E., Burjachs, F., Caceres, I., Canals, A., Benito, A Diez, C., Lozano, M., Mateos, A., Navazo, M., Rodriguez, J., Rosell, J., Arsuaga, J.L., 2008. The first hominin of Europe. Nature 452, 465-469. http://dx.doi.org/ 10.1038 /nature06815

Carrión, J.S. (Ed.), 2012. Paleoflora y Paleovegetación de la Península Ibérica e Islas Baleares. Universidad de Murcia, Secretariado PU, Murcia, Spain.

Carrión, J.S., Fernández, S., González-Sampériz, P., Gil-Romera, G., Badal, E., CarriónMarco, Y., López-Merino, L., López-Sáez, J.A., Fierro, E., Burjachs, F., 2010. Expected trends and surprises in the Lateglacial and Holocene vegetation history of the Iberian Peninsula and Balearic Islands. Review of Palaeobotany and Palynology 162, 458-475. http://dx.doi.org/10.1016/j.revpalbo.2009.12.007.

Carrión Marco, Y., 2005. La vegetación mediterránea y atlántica de la Península Ibérica: nuevas secuencias antracológicas. Diputación de Valencia.

Carrión Marco, Y., Ntinou, M., Badal Garcia, E., 2010. Olea europaea L. in the North Mediterranean Basin during the Pleniglacial and the Early-Middle Holocene. Quaternary Science Reviews 29, 952-968. http://dx.doi.org/10.1016/ j.quascirev.2009.12.015

Casabó, J., 2004. Paleolítico Superior final y Epipaleolítico en la Comunidad Valenciana. In: MARQ Museo Arqueológico de Alicante, Serie Mayor 3, p. 381.

Clark, A.E., 2008. Changes in Occupation Intensity during the Lower and Middle Paleolithic at Tabun Cave, Israel. Master's Paper. University of Arizona.

Clevis, Q., Tucker, G.E., Lock, G., Lancaster, S.T., Gasparini, N., Desitter, A., Bras, R.L., 2006. Geoarchaeological simulation of meandering river deposits and settlement distributions: a three-dimensional approach. Geoarchaeology 21, $843-$ 874.

Cortés Sánchez, M., 2010. El Paleolítico superior en el sur de la Península Ibérica. Un punto de partida a comienzos del siglo XXI. In: Mangado, X. (Ed.), El Paleolítico Superior Peninsular. Novedades del Siglo XXI. Homenaje al Profesor Javier Fortea. SERP, Barcelona, pp. 173-198.

Cowgill, G.L., 1977. The trouble with significance tests and what we can do about it American Antiquity 42, 350-368.

Davidson, I., 1976. Les Mallaetes and Monduver: the economy of a human group in prehistoric Spain. In: de Sieveking, G., Longworth, J., Wilson, K. (Eds.), Problems in Economic and Social Archaeology. Duckworth, London, pp. 483-499.

Davidson, I., 1989. La economia del final del paleolitico en la Espana oriental. Servicio de Investigacioń Prehistoŕica, Valencia.

Dibble, H.L., Schurmans, U.A., Iovita, R.P., McLaughlin, M.V., 2005. The measurement and interpretation of cortex in lithic assemblages. American Antiquity 70, 545-560.

Douglas, M.J., Holdaway, S.J., Fanning, P.C., Shiner, J.I., 2008. An assessment and archaeological application of cortex measurement in lithic assemblages. American Antiquity 73, 513.

Farrand, W.R., 1993. Discontinuity in the stratigraphic record: snapshots from Franchthi Cave. In: Goldberg, P., Nash, D.T., Petraglia, M.D. (Eds.), Formation Processes in Archaeological Context. Prehistory Press, Madison, WI, pp. 85-96.

Fullola Pericot, J.M., 1979. Las industrias líticas del Paleolítico superior ibérico. Servicio de Investigacion Prehistorica, Valencia.

García Puchol, O., Aura Tortosa, J.E. (Eds.), 2006. El Abric de la Falguera (Alcoi, Alacant). 8.000 años de ocupación humana en la cabecera del rio Alcoi. CAM (Caja de Ahorros del Mediterráneo) y Ajuntament d'Alcoi, Alicante.

Grove, M., 2009. Hunter-gatherer movement patterns: causes and constraints. Journal of Anthropological Archaeology 28, 222-233. http://dx.doi.org/10.1016 j.jaa.2009.01.003.
Iturbe, G., Fumanal, M.P., Carrión, J.S., Cortell, E., Martinez, R., Guillem, P.M., Garralda, M.D., Vandermeersch, B., 1993. Cova Beneito (Muro, Alicante): una perspectiva interdisciplinar. Recerques del Museu d'Alcoi 2, 23-88.

Iturbe Polo, G., Perez, E.C., 1982. Cova Beneito: avance preliminar. Saguntum (Papeles del laboratorio de arqueología de Valencia) 17, 10-44.

Jorda Pardo, J. Aura Tortosa, J.E., 2008. 70 fechas para una cueva: revisión crítica de 70 dataciones C14 del Pleistoceno superior y Holoceno de la Cueva de Nerja (Málaga, Andalucía, España). In: Espacio, tiempo y forma. Serie I, Prehistoria y arqueología, pp. 239-256.

Jorda Pardo, J., Maestro González, A., Aura Tortosa, J.E., Alvarez Fernández, E., Avezuela Aristu, B., Badal Garcia, E., Morales Pérez, J.V., Perez Ripoll, M., Villalba Currás, M.P., 2011. Evolución paleogeográfica, paleoclimática y paleoambiental de la costa meridional de la Península Ibérica durante el Pleistoceno superior. El caso de la Cueva de Nerja (Málaga, Andalucía, España). Boletín de la Real Sociedad Española de Historia Natural. Sección geológica 105, 137-147.

Kelly, R.L., 1992. Mobility/Sedentism: concepts, archaeological measures, and effects. Annual Review of Anthropology 21, 43-66. http://dx.doi.org/10.1146/ annurev.an.21.100192.000355.

Kelly, R.L., 1995. The Foraging Spectrum: Diversity in Hunter-Gatherer Lifeways. Smithsonian Institution Press, Washington, DC.

Kuhn, S.L., 1992. On planning and curated technologies in the Middle Paleolithic. Journal of Anthropological Research 48, 185-214.

Kuhn, S.L., 1994. A formal approach to the design and assembly of mobile toolkits. American Antiquity 59, 426-442.

Kuhn, S.L., 2004. Middle Paleolithic assemblage formation at Riparo Mochi. In: Johnson, A.L. (Ed.), Processual Archaeology: Exploring Analytical Strategies, Frames of Reference and Culture Process. Greenwood Publishing Group, Westport, CT, pp. 31-60.

Liu, Z., Otto-Bliesner, B.L., He, F., Brady, E.C., Tomas, R., Clark, P.U., Carlson, A.E., LynchStieglitz, J., Curry, W., Brook, E., Erickson, D., Jacob, R., Kutzbach, J., Cheng, J., 2009. Transient simulation of last deglaciation with a new mechanism for Bølling-Allerød warming. Science 325, 310-314. http://dx.doi.org/10.1126/science.1171041.

Lyman, R.L., 1979. Available meat from faunal remains: a consideration of techniques. American Antiquity, 536-546.

Mangado Llach, X., Petit i Mendizàbal, M.À., Fullola i Pericot, J.M., Bartrolí, R., 2007. El paleolític superior final de la cova del Parco (Alòs de Balaguer, la Noguera). Revista d'Arqueologia de Ponent 16/17, 45-62.

Martínez Valle, R., 2001. Caçcadors de petites preses. In: Villaverde Bonilla, V. (Ed.), De neandertals a cromanyons. L'inici del poblament humà a terres valencianes. Fundació General de la Universitat de València, Universitat de València, Valencia, pp. 129-130.

McDonald, G.H., Bryson, R.A., 2010. Modeling Pleistocene local climatic parameters using macrophysical climate modeling and the paleoecology of Pleistocene megafauna. Quaternary International 217, 131-137. http://dx.doi.org/10.1016/ j.quaint.2009.10.010

Metcalf, D., Barlow, K.R., 1992. A model for exploring the optimal trade-off between field processing and transport. American Anthropologist 94, 340-356.

Miller, A., Barton, C.M., 2008. Exploring the land: a comparison of land-use patterns in the Middle and Upper Paleolithic of the western Mediterranean. Journal of Archaeological Science 35, 1427-1437. http://dx.doi.org/ 10.1016/j.jas.2007.10.007.

Morrow, T.M., 1996. Lithic refitting and archaeological site formation processes: a case study from the Twin Dutch site, Greene County, Illinois. In: Odell, G.H. (Ed.), Stone Tools Theoretical Insights into Human Prehistory. Plenum Press, New York, pp. 345-373.

Neeley, M.P., Barton, C.M., 1994. A new approach to interpreting late Pleistocene microlith industries in southwest Asia. Antiquity 68, 275-288.

NOAA, 2006. ETOPO2v2 Global Gridded 2-minute Database. National Geophysical Data Center, National Oceanic and Atmospheric Administration, U.S. Dept. of Commerce. http://www.ngdc.noaa.gov/mgg/global/etopo2.html.

Olària, C., 1999. Cova Matutano (Vilafamés, Plana Alta, Castellón). In: Un modelo ocupacional del Magdaleniense superior-final en le vertiente mediterrénea peninsular. Monografies de Prehistòria i Arqueologia Castellonenques, vol. 5. Castelló.

Pérez Ripoll, M., 2004. La consommation humaine des lapins pendant le Paléolithique dans la région de Valencia (Espagne) et l'étude des niveaux gravétiens de La Cova de les Cendres (Alicante). In: Petits animaux et sociétés humaines. Du complément alimentaire aux ressources utilitaires. XXIVe Rencontres Internationales d'Archéologie et d'Histoire d'Antibes, pp. 191-206.

Pérez Ripoll, M., Martínez Valle, R., 2001. La caza, el aprovechamiento de las presas y el comportamiento de las comunidades cazadoras prehistóricas. In: Villaverde Bonilla, V. (Ed.), De Neandertales a Cromañones. El inicio del poblamiento humano en tierras valencianas. Universitat de València, Valencia, pp. 119-124.

Phillips, S.J., Dudík, M., 2008. Modeling of species distributions with Maxent: new extensions and a comprehensive evaluation. Ecography 31, 161-175. http:// dx.doi.org/10.1111/j.0906-7590.2008.5203.x.

Riel-Salvatore, J., Barton, C.M., 2004. Late Pleistocene technology, economic behavior and land-use dynamics in southern Italy. American Antiquity 69, 273-290.

Riel-Salvatore, J., Barton, C.M., 2007. New quantitative perspectives on the MiddleUpper Paleolithic transition: the view from the northern Mediterranean. In: Riel-Salvatore, J., Clark, G.A. (Eds.), Early Upper Paleolithic "Transitional" Industries: New Questions, New Methods. British Archaeological Reports, Oxford.

Riel-Salvatore, J., Negrino, F., 2009. Early Upper Paleolithic population dynamics and raw material procurement patterns in Italy. In: Camps, M., Szmidt, C. (Eds.), The Mediterranean from 50,000 to 25,000 BP: Turning Points and New Directions. Oxbow Books, Oxford, pp. 211-230. 
Riel-Salvatore, J., Popescu, G., Barton, C.M., 2008. Standing at the gates of Europe: human behavior and biogeography in the Southern Carpathians during the Late Pleistocene. Journal of Anthropological Archaeology 27, 399-417.

Ripoll López, S. (Ed.), 1988. La Cueva de Ambrosio (Almería, Spain): y su posición cronoestratigráfica en el Mediterraneo Occidental. BAR.

Román Monroig, D., 2010. El poblament del final del Plistocé en les comarques del nord del País Valencià a partir de l'estudi tecno-tipològic de la indústria lítica. Servei de Publicacions Universitat de València, Valencia.

Ruter, A., Arzt, J., Vavrus, S., Bryson, R.A., Kutzbach, J.E., 2004. Climate and environment of the subtropical and tropical Americas $(\mathrm{NH})$ in the mid-Holocene: comparison of observations with climate model simulations. Quaternary Science Reviews 23, 663.

Sandgathe, D.M., 2006. Examining the Levallois Reduction Strategy from a Design Theory Point of View. Archaeopress, Oxford.

Schollmeyer, K.G., Driver, J.C., 2012. Settlement patterns, source-sink dynamics, and artiodactyl hunting in the prehistoric U.S. Southwest. Journal of Archaeological Method and Theory. http://dx.doi.org/10.1007/s10816-012-9160-5. http://www.springerlink.com/index/10.1007/s10816-012-9160-5.

Siddall, M., Rohling, E.J., Almogi-Labin, A., Hemleben, C., Meischner, D., Schmelzer, I., Smeed, D.A., 2003. Sea-level fluctuations during the last glacial cycle. Nature 423, 853-858. http://dx.doi.org/10.1038/nature01690.

Speth, J.D., Spielmann, K.A., 1983. Energy source, protein metabolism, and huntergatherer subsistence strategies. Journal of Anthropological Archaeology 2,1-31.

Szuter, C.R., Bayham, F.E., 1989. Sedentism and prehistoric animal procurement among desert horticulturalists of the North American Southwest. In: Kent, S. (Ed.), Farmers as Hunters: the Implications of Sedentism. Cambridge University Press, Cambridge.

Torregrosa, P., Jover Maestre, FJ., López Seguí, E., 2011. Benàmer (Muro d'Alcoi, Alicante). Mesolíticos y Neolíticos en las tierras meridionales valencianas. Servicio de Investigacion Prehistorica, Valencia.

Torrence, R., 1989. Time, Energy and Stone Tools. Cambridge University Press, Cambridge [Cambridgeshire]; New York.

Van Andel, T.H., 2002. The climate and landscape of the middle part of the Weichselian Glaciation in Europe: The Stage 3 Project. Quaternary Research 57, 2-8. http://dx.doi.org/10.1006/qres.2001.2294.

Villaverde Bonilla, V., 2001. El Paleolítico superior: El tiempo de los cromañones. Periodización y características. In: Villaverde Bonilla, V. (Ed.), De Neandertales a
Cromañones. Los inicios del poblamiento humano en el País Valenciano. Universitat de València, Valencia, pp. 177-218.

Villaverde Bonilla, V., Martínez Valle, R., 1995. Características culturales y económicas del Paleolítico superior en el Mediterráneo español. In: Villaverde Bonilla, V. (Ed.), Los últimos cazadores. Transformaciones culturales y económicas durante el Tardiglaciar y el Incio del Holoceno. Instituto Juan Gil Albert, Alicante, pp. 79-118

Villaverde Bonilla, V., Martínez Valle, R., Badal Garcia, E., Guillem Calatayud, P.M., García, R., Menargues, J., 1999. El Paleolítico superior de la Cova de les Cendres (Teulada-Moraira, Alicante). Datos proporcionados por el sondeo efectuado en los cuadros A/B-17. Archivo de Prehistoria Levantina 23, 9-65.

Villaverde Bonilla, V., Román, D., Martínez, R., Badal Garcia, E., Pérez Ripoll, M. Tormo, C., Bergadà Zapata, M.M., Calatayud, G., Miquel, P., 2010. El Paleolítico superior en el País Valenciano. In: Novedades y perspectivas. El Paleolítico superior peninsular: novedades del siglo XXI:[homenaje al profesor Javie Fortea]. Universidad de Alicante, Alicante, pp. 85-114.

Villaverde Bonilla, V., Román, D., Peréz Ripoll, M., Bergadà, M.M., Real, C., 2012. The end of the Upper Palaeolithic in the Mediterranean Basin of the Iberian Peninsula. Quaternary International 272-273, 17-32. http://dx.doi.org/10.1016/ j.quaint.2012.04.025

Villaverde, V., Aura Tortosa, J.E., Barton, C.M., 1998. The Upper Paleolithic in Mediterranean Spain: a review of current evidence. Journal of World Prehistory 12 121-198.

Voinov, A.A., DeLuca, C., Hood, R.R., Peckham, S., Sherwood, C.R., Syvitski, J.P.M., 2010. A community approach to earth systems modeling. Eos, Transactions American Geophysical Union 91, 117. http://dx.doi.org/10.1029/ $2010 \mathrm{E} 0130001$.

Waechter, J.d'A., 1951. Excavations at Gorham's Cave, Gibraltar. Proceedings of the Prehistoric Society 17, 83-92.

Waechter, J.d'A., 1964. The Excavation of Gorham's Cave, Gibraltar, 1951-54, vol. 4 Institute of Archaeology Bulletin, University of London, pp. 189-221.

Zilhão, J., Angelucci, D.E., Badal-García, E., Lucena, A., Martín, I., Martínez, S., Villaverde Bonilla, V., Zapata, J., 2010. Dos abrigos del Paleolítico superior en Rambla Perea (Mula, Murcia). In: El Paleolítico superior peninsular: novedades del siglo XXI:[homenaje al profesor Javier Fortea]. Universidad de Alicante, Alicante, pp. $137-148$ 